\title{
How government subsidies promote the growth of entrepreneurial companies in clean energy industry: An empirical study in China
}

Huatao Peng and Yang Liu

The self-archived postprint version of this journal article is available at Linköping University Institutional Repository (DiVA):

http:/ / urn.kb.se/ resolve?urn=urn:nbn:se:liu:diva- 148077

N.B.: When citing this work, cite the original publication.

Peng, H., Liu, Y., (2018), How government subsidies promote the growth of entrepreneurial companies in clean energy industry: An empirical study in China, J ournal of Cleaner Production, 188, 508-520. https:// doi.org/ 10.1016/j.jclepro.2018.03.126

Original publication available at:

https:// doi.org/ 10.1016/j.jclepro.2018.03.126

Copyright: Elsevier

http:// www.elsevier.com/

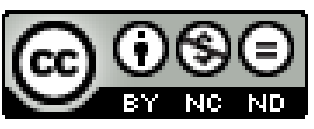




\section{Accepted Manuscript}

How government subsidies promote the growth of entrepreneurial companies in clean energy industry: An empirical study in China

Huatao Peng, Yang Liu

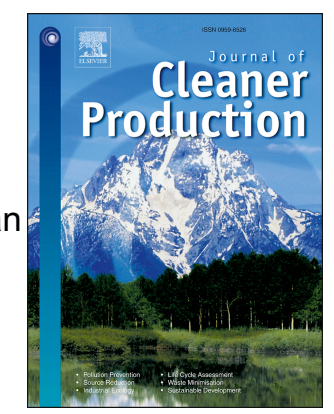

PII:

S0959-6526(18)30787-X

DOI:

10.1016/j.jclepro.2018.03.126

Reference:

JCLP 12384

To appear in: Journal of Cleaner Production

Received Date: 12 October 2017

Revised Date: 2 February 2018

Accepted Date: 12 March 2018

Please cite this article as: Peng H, Liu Y, How government subsidies promote the growth of entrepreneurial companies in clean energy industry: An empirical study in China, Journal of Cleaner Production (2018), doi: 10.1016/j.jclepro.2018.03.126.

This is a PDF file of an unedited manuscript that has been accepted for publication. As a service to our customers we are providing this early version of the manuscript. The manuscript will undergo copyediting, typesetting, and review of the resulting proof before it is published in its final form. Please note that during the production process errors may be discovered which could affect the content, and all legal disclaimers that apply to the journal pertain. 


\section{ACCEPTED MANUSCRIPT}

1 How government subsidies promote the growth of entrepreneurial companies in clean

2 energy industry: An empirical study in China

3

$$
\text { Huatao Peng }{ }^{\mathrm{a}} \text { and Yang Liu* }{ }^{\mathrm{b}, \mathrm{c} 1}
$$

${ }^{a}$ School of Management, Wuhan University of Technology, 122 Luoshi Road, Hongshan District, Wuhan 430070, People's Republic of China

6

${ }^{b}$ Department of Management and Engineering, Linköping University, SE-581 83 Linköping, Sweden

${ }^{c}$ Department of Production, University of Vaasa, PL 700, 65101 Vaasa, Finland

*Corresponding author.

Tel: +46 73661 7727; Email: yang.liu@liu.se; yang.liu@uva.fi (Yang Liu) 


\section{How government subsidies promote the growth of entrepreneurial companies in clean energy industry: An empirical study in China}

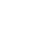

(1)

(1)
(1)

Abstract Under the context that entrepreneurial risk in clean energy industry has become increasingly complex, government subsidies are helpful to guide and promote the entrepreneurial companies' survival and development. This paper explored the roles of government subsidies, more specifically, in forms of government subsidies beforehand and government subsidies afterwards on the relationship between R\&D and entrepreneurial companies' growth, particularly in the clean energy industry. To delve deeper into the roles, this paper analysed data from the 2013 and 2014 annual reports of 58 listed companies in clean energy industries in China. By using a moderating effect model, this paper derived following conclusions: (1) R\&D investment does not have a lag effect on entrepreneurial companies' growth; (2) Government subsidies beforehand has negative moderating effects on the relationship between R\&D investment and entrepreneurial companies' growth; (3) Government subsidies afterwards has positive moderating effects on the relationship between R\&D investment and entrepreneurial companies' growth. This paper helped to understand the difference between the functions of government subsidies beforehand and government subsidies afterwards. To some extent, the results can revise prior studies about the function of government subsidies to influence the relationship between R\&D and entrepreneurial companies' growth. The results will also be helpful for the government to evaluate the performance of government subsidies and design appropriate subsidies strategies.

Keywords: government subsidies; research and development (R\&D); entrepreneurial companies; clean energy industry 


\section{Introduction}

Subsidies are regarded as an important economic intervention tool to solve the problems of market failure. It should be noted that they generate great influence on companies' R\&D activities (GÖRg and Strobl, 2007), export competitiveness (Desai and Hines, 2008), production efficiency (Azzimonti et al., 2008), etc. For entrepreneurial companies, government subsidies are important funding sources, which help them to overcome the constraint of capital shortage (Claro, 2006).

Many scholars have demonstrated the relationship between government support for entrepreneurial companies' R\&D spending and entrepreneurial companies' growth from all angles. Clean energy is a rising industry that has been rising rapidly. In the early stage of development, there were a series of problems, such as market failure and technology spillover, which needed government subsidies to intervene. The government should take effective incentive mechanisms, such as subsidies beforehand and subsidies afterwards, to guide clean energy start-ups to increase technological innovation (Batlle, 2011). Soratana et al. (2014) researched Chinese companies and found that there was a significant positive correlation between government subsidies and new energy enterprises' performance. Impeded by the market entry barriers, it is not easy for entrepreneurial companies to open the new market and achieve relatively high market share (Jing et al., 2013; Shao et al., 2014). It is possible for the entrepreneurial companies to achieve funding that they need from bank loans and venture investment. However, it is much easier for them to obtain the government subsidies, which help to reduce asset-liability ratio greatly (Hsu et al., 2009). When the entrepreneurial companies have received the subsidies, it means that their legal status has been approved by the government, which in turn helped them to achieve more resources (Söderblom et al., 2015). It is essential for the entrepreneurs to handle the relationship with the related departments if they want to achieve the subsidies, and in this process their social network shall be expanded and the growth of their companies shall be benefited (Lahr and Mina, 2016). In addition, government subsidies motivated entrepreneurial companies to increase their investment in R\&D and help to increase $R \& D$ efficiency (Meuleman and De Maeseneire, 2012; Zhang and Wang, 2017). Other scholars, like Wang et al. (2013) also found that government subsidies can increase entrepreneurial companies' current yield.

According to the time sequence of government subsidies and companies' R\&D, government subsidies can be divided into two parts: government subsidies beforehand (GSB) and government subsidies afterwards (GSA) (Hud and Hussinger, 2015). The results of some previous in-depth studies aimed at the influence of government support on the relationship between R\&D and entrepreneurial companies' growth (ECG). For example, Yu et al. (2016) found that both GSB and GSA have positive effects on the companies' R\&D activities, and in general, GSB are more influential in promoting companies' R\&D activities comparing with 
GSA. GSB decreased entrepreneurial companies' financial risk and show government's positive attitude to these companies (Lee et al., 2014). Some researchers found that GSA are more effective than GSB as GSA represent government's approval of entrepreneurial companies' R\&D activities (Czarnitzki and Kraft, 2004). The empirical research on the value of government subsidies to the listed companies in China has proved government subsidies' direct influence (Zeng et al., 2013). However, government subsidies exert different influences on different companies and different companies' behaviours. For example, Almus and Czarnitzki (2003) found that government subsidies generated great influence on companies' R\&D activities (GÖRg and Strobl, 2007), while GÖRg and Strobl (2007) found government subsidies influenced companies' sustainable profit growing ability. Moreover, Girma et al. (2009) found that government subsidies enhanced companies' competitiveness and Claro (2006) found that they decreased the constraint of limited capital. The negative effects of government subsidies also should not be neglected. Government subsidies probably lead to overproduction and efficiency loss, hindering companies' sustainable development. Lee et al. (2014) found that government subsidies increased entrepreneurial companies' initial investment cost required as they spend the money on the acquisition of the subsidies.

From the above analysis, at present there was no unified conclusion about how the GSB and GSA affected the relationship between R\&D input and output of entrepreneurial enterprises (Dever, 2010). The research on GSB and GSA for entrepreneurial enterprises mainly discussed its impact on the economic performance of enterprises (Girma et al., 2007), and did not focus on the development and growth of venture enterprises. At the same time, the unique attributes of the clean energy field were ignored. There was little research analyses the impact of GSB and GSA on the enterprises in the clean energy industry.

In this study, the theory of externality was used as the theoretical connotation. The existence of externality breaks the marginal condition for the optimal allocation of resources and makes the allocation of resources deviate from the Pareto optimal state. The clean energy related knowledge leaks or spillovers in the process of R\&D innovation in the development and innovation of clean energy enterprises leads to lower private returns, which increase the risk of R\&D investment and independent innovation activities (Clarysse et al, 2009). The government participates in the innovative research and development activities of clean energy enterprises in the form of GSB and GSA, which can effectively solve the problem of no optimal allocation of resources caused by the inconsistency of marginal social income and private income.

In this study, the influence mechanism of government subsidies on the relationship between entrepreneurial companies' R\&D investment and growth were studied through analysing the moderating effects of GSB and GSA. The article is constructed as follows. In section 2, the theoretical framework will be set up. In section 3, different hypotheses are developed from 
the literature. In section 4, the samples, variables and research methods are discussed afterwards. In section 5, the empirical analysis is described and finally the conclusions and implications on management are discussed in section 6 .

\section{Theoretical background}

Generally speaking, entrepreneurial companies rely on the government subsides to lower cost and deal with risks especially under the condition of weak institutional contexts in emerging market economies (Du and Mickiewicz, 2016). On the other hand, the current market lacked enough incentives to encourage clean technology innovation, so clean energy enterprises must rely on government support (Acemoglu D et al, 2012). The government has designed different subsidy policies to adapt to the specific nature of the enterprise to support the development of the clean technology industry (Simón Moya, 2015). Therefore, more government subsidies (including GSB and GSA) means the entrepreneurial companies get more benefits from the participations in politics (Feng et al., 2015), which can reduce the innovation cost of clean technology and promote entrepreneurial companies' development.

\subsection{Government subsidies beforehand}

GSB referred to the subsidies that government provide economic support to the companies before the beginning of companies' R\&D activities through financial allocation (Wang and Zhang, 2016). It should be mentioned that GSB always have clear goals, which meant that when the government appropriated the subsidies to the companies in advance, it stipulated specifically where these subsidies are going, and how the money is being used. The companies that received these subsidies should utilize the money according to the government rules and regulations. With the promotion of clean energy industry in the world, government subsidies have become a common phenomenon, which include different ways. There were differences in the use of government subsidies among different growth enterprises. The main goal of GSB was to help entrepreneurial companies to solve the financing problems in the early stage of R\&D, and the amount of the subsidies is not influenced by the R\&D results or the marketing of $R \& D$ results (Du and Mickiewicz, 2016).

Compared with GSA, GSB were more direct. They aimed at reducing R\&D risk and R\&D expenditure. GSB were commonly used by the governments of the members of Organization for Economic Cooperation and Development (OECD), and the amount of the subsidies occupied more than $1 \%$ of the GDP, which increased at a very high speed (Soratana et al., 2014). Because of the characteristics of high investment, long period and uncertainty of income of clean technology, clean energy companies' R\&D was often accompanied by high risks, and GSB can reduce companies' R\&D expenditure and help them to avoid the market failure of technology innovation. As a result, GSB can greatly improve the success rate of 
companies' R\&D (Dai and Cheng, 2015). Similar as the opinion of Dai and Cheng (2015), Bronzini and Piselli (2016) also found that GSB can lower the barriers for the entrepreneurs to start new companies and motivate the companies with the marketing potential to carry out more R\&D activities. Through empirical research of more than 800 high-tech companies in Beijing, $\mathrm{Hu}$ and $\mathrm{Hu}$ (2001) found that the amount of GSB is positively related to the companies' R\&D investment.

GSB and companies' R\&D activities were complementary to each other. To be specific, GSB helped to reduce the risk of technological innovation in clean energy enterprises and provide more adequate financial support for internal R\&D activities, thereby positively influenced the output of companies' R\&D activities, and the increase of companies' R\&D investment attracted more subsidies by attracting the government's attention (Meuleman and De Maeseneire, 2012; Wu et al., 2016). Moreover, through the research of different industries, Zhang et al. (2014) found that GSB were more influential in light industries than in heavy industries. Therefore, it is reasonable and scientific to say that the increase in the amount of GSB was conducive to companies' R\&D activities.

\subsection{Government subsidies afterwards}

Different with GSB, GSA referred to the supporting policy that government reimbursed certain money to the companies when the projects achieved anticipated achievement or after the projects have been finished. Normally, the main form of GSA was tax reduction. It encouraged enterprises to use renewable energy, indirectly helped enterprises to reduce $R \& D$ expenditure, and encouraged enterprises to participate in $R \& D$ activities through tax reduction and other policy subsidies (Janssens and Zaccour, 2014). In addition to tax cuts, the government adopted the way of subsidy for later liquidation, such as new energy vehicles, in the field of partial clean energy to improve the access threshold of clean energy sector, aimed to improve the access threshold of clean energy industry, to avoid excessive reliance on subsidy policies and "cheat subsidy" action (Zhang X and Zhang C, 2015). Comparing to the GSB, GSA are much more flexible. Companies' R\&D scale and methods are not influenced by government intervention. As a result, GSA assured the independence of companies' R\&D which was operated under the condition of marketization mechanism (Antonelli and Crespi, 2013).

The main research results regarding the relationship between GSA and companies' R\&D activities can be listed as follows. GSA motivated the companies to be involved in the R\&D activities, but the influence of GSA differed greatly in different countries and different areas (Kleer, 2010). Through empirical research of 17 different countries, Alexander and Organ (2015) found that government subsidies in certain degree motivated the whole society to start new businesses. Moreover, it should be mentioned that GSA have different effects on different entrepreneurial companies. They exerted great influence on the high-tech 
181

182

183

184

185

186

187

188

189

190

191

192

193

194

195

196

197

198

199

200

201

202

203

204

205

206

207

208

209

210

211

212

213

214

215

216

companies, like biological medicine companies, high-end equipment manufacturing companies etc. (Clausen, 2009).

\subsection{The growth of Entrepreneurial companies}

According to the opinion of Global Entrepreneurship Monitor (GEM), those companies which have been established for more than 42 months but still have the consciousness of innovation, competition and growth belong to entrepreneurial companies. With the government's increasing support for the clean energy venture, the number of enterprises entering the clean energy industry was growing (Malen and Marcus, 2017). The nature of entrepreneurial companies' growth involved in the expansion of companies' scale, the maturity of companies' management system, the stability of the organizational structure, and the market scale of companies' products (Meutia and Ismail, 2012). Reijonen et al. (2015) pointed out that the indicators measuring entrepreneurial companies' growth included the level of total assets, the level of net assets, the return on total assets, the return on the net assets, and the growth rate of net cash flow. To be specific, the level of total assets and the level of net assets reflected entrepreneurial companies' scale, and the return on total assets, the return on the net assets, and the growth rate of net cash flow reflected entrepreneurial companies' prospects.

Researchers' opinions regarding to the development stage of entrepreneurial companies were different. According to the changes of the managing mode of R\&D activities, Soininen et al. (2012) divided the development stage into four parts, which were, self-execution stage, supervision and control stage, organizational management stage, and departmentalization coordination. To be specific, it meant that entrepreneurs directly controlled the R\&D activities in the initial stage, while at the final stage, the R\&D activities were mainly influenced by the cooperation among companies' internal departments, reflecting the expansion of companies' market scale and the maturity of the management system. Wang et al. (2011) held different opinions of how the development stage of entrepreneurial are divided. They divided the entrepreneurial companies' development into the incubation stage, infancy stage, go-go stage, and adolescent stage according to the characteristics of entrepreneurial companies, moreover, they specifically pointed out that after the adolescent stage, the companies were no longer entrepreneurial companies (Wang et al., 2011). Particularly, the core tasks for each stage were very different.

Bontempi and Prodi (2009) thought that the development process of entrepreneurial companies was mainly distributed into two stages: strategy replication stage and strategy innovation stage. In the strategy replication stage, the entrepreneurial companies' lack of the marketing experience, so required them to learn, analyse and replicate competitors' strategies to avoid the unknown risks. In the strategy innovation stage, entrepreneurial 
companies have already obtained certain achievements and experiences, so in this stage, they endeavour to achieve the sustainable development by utilizing the new strategies.

\section{Hypotheses}

221 It is no doubt that companies that continue to conduct R\&D activities were more likely to innovate their knowledge and skills (Colombo et al., 2009), investment in R\&D helped companies to expand their business and increase their market competitiveness (Coad and Rao, 2008; Artz et al., 2010). However, it did not mean absolutely high performance and high sales revenue. Researchers have already revealed that the effects of investment in R\&D on the growth of entrepreneurial companies differed greatly within different industries. Diaz Arias and van Beers (2013) found that the investment in the R\&D of renewable energy resources has negative effects on the research and patent application of renewable energy technologies, especially the technologies related to solar energy and wind energy. They thought that the investment in R\&D had negative effects on companies' performance rather than positive effects, and the enterprise life for those companies engaged in research and development or companies start in the development was usually short. R\&D investment in high-risk projects may not improve their key financial performance indicators. Only when the enterprise R\&D activities achieved a breakthrough, it will improve the business performance (Brinckmann et al., 2011). Beason and Weinstein (1996) directly pointed out that investment in R\&D decreased companies' growth speed and brought scale descending effects. The more investment in R\&D by companies, the higher uncertainty the companies were confronted with. For entrepreneurial companies, they were often short of money. Therefore, if they invest too much in the R\&D, the business risks will be increased tremendously (Nitsch, 2009), echoing the opinion of Dzhumashev et al. (2016). He put forward that entrepreneurial companies which pay too much attention on R\&D faced higher financial risks compared with those show less concern on R\&D. Due to scale disadvantages, increasing $R \& D$ investment will have a greater pressure on the entrepreneurial companies. They may not directly use R\&D investment to improve business situation but try to promote business growth in a simple and quick way (Berrone et al., 2014). Eveleens (2010) divided R\&D into three different kinds, which were, basic research, strategic basic research, and experimental development. Basic research barely shown any value in application, strategic basic research and experimental development both had relatively long development period and consumed a lot of money. Therefore, the high investment in R\&D in certain condition just hindered entrepreneurial companies' growth. Especially for clean energy enterprises as the main body and direct beneficiaries of clean technology, although the development of clean energy enterprises needed technical support, the protection of related patents and intellectual property rights was weak. Investment in R\&D cannot bring the entrepreneurial companies with high sales in short terms. Investment in R\&D will inject the entrepreneurial 
companies with technological innovation vitality and help them to increase the sales period (Yang and Lin, 2008; Coad and Rao, 2008). As a result, the following hypothesis can be derived:

\section{H1: R\&D investment has a lag effect on entrepreneurial companies' growth.}

259

260

261

262

263

264

265

266

267

268

269

270

271

272

273

274

275

276

277

278

279

280

281

282

283

284

285

286

287

288

289

290

291

292

Government often used subsidies to make up the market failure and improved its economic intervention capabilities (Schwartz and Clements, 1999). The clean energy field has the characteristics of high risk and long recovery period, and once the research was successful, it has great positive externality and high income. According to the externality theory, for industries with positive externalities, the government should restore the incentive function of the market through subsidies, so that the supply of positive externalities of clean energy enterprises could reach the best level of society (Yin and Lin, 2010). The development and promotion of related technologies in the field of clean energy mainly depend on government subsidy intervention. Under the joint efforts of the government and enterprises, clean energy related technology, economic and political knowledge can be better integrated and deployed, promoting the development of enterprises and the technological progress of the industry (Ardito et al., 2014). For example, government provided advance subsidies to influence companies' R\&D behaviours (GÖRg and Strobl, 2007). Japan Ministry of International Trade and Industry offered cheap money to targeted industries to motivate R\&D activities for entrepreneurial companies to promote the development of entrepreneurial companies (Parker, 2008). Desai and Hines (2008) thought that investment in R\&D helped companies to achieve high revenues and assured sustainable development for them. However, the R\&D of entrepreneurial companies in the growth stage was restricted by funds and was very hard to predict, as it has no clear goals. As a result, R\&D risk of entrepreneurial companies was comparatively higher (Coad et al., 2016). Almus and Czarnitzki (2003) also found that GSB can effectively promote R\&D. For example, in some specific industries or areas, GSB can protect the companies that without high revenues by lowing their R\&D expenditure (Lee, et al. 2014). The government subsidized the knowledge acquisition costs of the entrepreneurial companies, which could help them carry out R\&D activities easier and make knowledge of schools and other social research institutions more convenient to transfer to entrepreneurial companies. This can promote the transformation of knowledge and the development of entrepreneurial companies (Felzensztein et al., 2013; Shao et al., 2017). Moreover, GSB motivated entrepreneurial companies R\&D enthusiasm (Bronzini and Piselli, 2016). Generally speaking, R\&D investment of companies in the mature stage have more stable effects as R\&D investment of entrepreneurial companies had no specific goals. Therefore, it is reasonable to assume that the development of entrepreneurial companies was closely related with GSB. GSB not only helped to reduce entrepreneurial companies' R\&D expenditure, but also helped them to find the right $R \& D$ direction. Based on the analysis above, following hypothesis can be derived. 
H2: GSB have positive moderating effects on the relationship between R\&D investment and entrepreneurial companies' growth.

GSA referred to the supporting method that government departments appropriated certain proportional reimbursement when the projects achieved anticipated achievement or after the projects have been finished. In recent years, the clean energy industry has begun to take shape with the government's increasing efforts to cultivate the clean energy market. A higher demand was put forward for the research strength and independent research and development level of entrepreneurial enterprises. GSA can effectively stimulate the entrepreneurial enterprises in clean energy industry to improve R\&D capability (Zhang $\mathrm{H}$, et al, 2014). To encourage innovation and product development of entrepreneurial companies, some governments will take related measures to reduce R\&D costs (Wise \& Miles, 2003), such as tax deduction, which can help entrepreneurial companies to reduce their financial stress before the end of the fiscal year and help companies achieve their next year's strategic goals (Patzelt and Shepherd, 2009). Zhang et al. (2003) put forward that GSA were often more effective than GSB in promoting companies' sustainable development. Koga (2005) suggested that government subsidies were not available for all the companies. Influenced by national policies and R\&D motivation, it is possible that government gave the advance subsidies to the projects without good prospect (Lerner, 1999).

As a result, compared to GSB, GSA were more reasonable as the government gives out the reimbursements based on the practical R\&D effects. On the one hand, GSA promoted the companies to fully utilize the internal R\&D resources and to enhance their internal cooperation. On the other hand, they helped to enhance the companies' relationship with external organizations (universities, research institutions, etc.), so it is reasonable to assume that the companies can have a relatively higher success rate. Therefore, the following hypothesis can be developed.

H3: GSA have positive moderating effects on the relationship between R\&D investment and entrepreneurial companies' growth.

Fig.1 summarizes the 3 hypotheses above in this study.

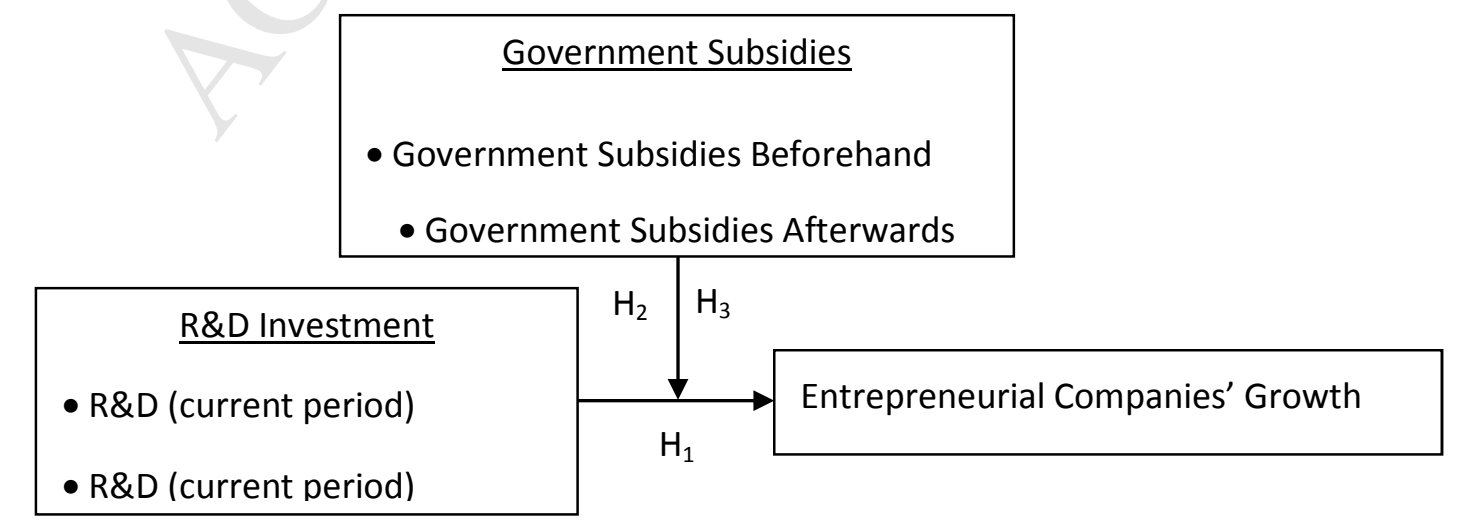

Fig. 1. The hypotheses models presented in this study 


\section{Data and Methods}

329

330

331

332

333

334

335

336

337

338

339

340

341

342

343

344

345

346

347

348

349

350

351

352

353

354

To further study the influence of government subsidies on the relationship between entrepreneurial companies' own R\&D investment and their growth, it is necessary to get the data about GSB, GSA, R\&D and entrepreneurial companies' growth, to build up the proposed logistic framework.

\subsection{Data}

As shown in Table 1, during 2007 to 2013, the pumped storage energy of China's hydropower industries has grown from 130 million KW to 270 million KW with an average annual growth rate of $17.9 \%$. It is estimated that by 2020 , the scale of the pumped storage energy will reach 300 million KW. The annual output of solar cells of China's solar photovoltaic industries has increased from $1200 \mathrm{MW}$ to $18073 \mathrm{MW}$, with a tremendous average annual growth rate of $234.3 \%$. The estimated electric output for solar energy is $21600 \mathrm{MW}$ for the year 2020. The installed capacity of wind power industries in China has grown from $6050 \mathrm{MW}$ to $91500 \mathrm{MW}$ for the same period, and its average annual growth rate is $235.3 \%$. It is estimated that by 2020 its capacity will be up to $120000 \mathrm{MW}$. The powergenerating scale of China's biomass power generation has increased from $2200 \mathrm{MW}$ to 9600 MW, with an annual growth rate of $56.1 \%$. It is predicted that its scale will reach $22000 \mathrm{MW}$ by 2020. The output of Bio-solid fuel in China has grown from 550000 tons to 5.1 million tons, and its average annual growth rate is $137.9 \%$. By 2020 , it is estimated that its output will increase to 50 million tons.

In addition, according to the forecast report of CCID (China Center for Information Industry Development) Consulting Company Limited by 2020, the scale of Chinese biogas industry will reach 440 cubic meters; the scale of the fuel ethanol industry will reach 12.7 billion litres; the scale of the biodiesel industry will reach 2.4 billion litre; the scale of the geothermal industry will reach 1200 tonne of coal equivalent (TCE); the scale of the tidal power industry will reach $100 \mathrm{MW}$; and the scale of the nuclear power industry will reach $44968 \mathrm{MW}$.

Table 1. The development status of main clean energies in China (2007-2013)

\begin{tabular}{|l|l|l|l|l|l|l|l|l|l|}
\hline Type & Unit & \multicolumn{2}{|l|}{ The annual capacity } \\
\cline { 3 - 11 } & 2007 & 2008 & 2009 & 2010 & 2011 & 2012 & 2013 & 2020 \\
\hline $\begin{array}{l}\text { Hydropower } \\
\text { (pumped } \\
\text { storage) }\end{array}$ & $\begin{array}{l}\text { Hundred } \\
\text { Million } \\
\text { KW }\end{array}$ & 1.3 & 1.5 & 1.8 & 2.1 & 2.3 & 2.4 & 2.7 & 3.0 \\
\hline Solar & MW & 1200 & 2126 & 3460 & 5660 & 9848 & 15067 & 18073 & 21600 \\
\hline
\end{tabular}




\begin{tabular}{|l|l|l|l|l|l|l|l|l|l|}
\hline $\begin{array}{l}\text { photovoltaic } \\
\text { (annual output } \\
\text { of solar cells) }\end{array}$ & & & & & & & & & \\
\hline $\begin{array}{l}\text { Wind power } \\
\text { (installed } \\
\text { wind capacity) }\end{array}$ & MW & 6050 & 13240 & 26270 & 40720 & 61080 & 78520 & 91500 & 120000 \\
\hline $\begin{array}{l}\text { Biomass power } \\
\text { generation } \\
\text { (power- } \\
\text { generating } \\
\text { scale) }\end{array}$ & MW & 2200 & 3150 & 4300 & 5500 & 6700 & 8000 & 9600 & 22000 \\
\hline $\begin{array}{l}\text { Bio-solid fuel } \\
\text { (Output) }\end{array}$ & $\begin{array}{l}\text { Thon } \\
\text { Thons }\end{array}$ & 55 & 95 & 145 & 210 & 295 & 365 & 510 & 5000 \\
\hline
\end{tabular}

There were totally 66 listed companies that belong to clean energy industries in 2014 in

356 China. To empirically test the hypotheses, this study used data from the 2013 and 2014

357 annual reports of the total 66 companies. The basic information of these samples is shown in

358 Appendix. According to the main products, the firms can be subdivided into 10 categories,

359 and 16 firms belong to solar energy industry, which occupies the highest proportion. Most of

360 these entrepreneurial firms have relatively long development history and relatively big size

361 as can be seen from the table 1 that $86.4 \%$ of the firms have more than 10 years

362 development history and $62.1 \%$ of the firms have more than 2000 employees (as shown in

363 Table 2).

Table 2. Basic information of 66 listed companies in China's clean energy industry

\begin{tabular}{|l|l|l|l|}
\hline Classification & Sub-classification & Number & Percentage \\
\hline \multirow{5}{*}{ Industrial } & Wind power & 7 & $10.6 \%$ \\
\cline { 2 - 4 } & Nuclear power & 6 & $9.1 \%$ \\
\cline { 2 - 4 } & Photovoltaic power & 7 & $10.6 \%$ \\
\cline { 2 - 4 } & Solar energy & 16 & $24.2 \%$ \\
\cline { 2 - 4 } & Hydrogen & 3 & $4.5 \%$ \\
\cline { 2 - 4 } & Lithium battery & 2 & $3.0 \%$ \\
\cline { 2 - 4 } & Biological energy & 8 & $12.1 \%$ \\
\cline { 2 - 4 } & Tidal energy & 1 & $1.5 \%$ \\
\cline { 2 - 4 } & Geothermal energy & 11 & $16.7 \%$ \\
\cline { 2 - 4 } & Hydropower & 5 & $7.6 \%$ \\
\hline Age & $1-5$ & 3 & \\
\hline
\end{tabular}




\begin{tabular}{|l|l|l|l|}
\hline \multirow{5}{*}{} & $6-10$ & 6 & $9.1 \%$ \\
\cline { 2 - 4 } & $11-20$ & 29 & $43.9 \%$ \\
\cline { 2 - 5 } & $21-30$ & 24 & $36.4 \%$ \\
\cline { 2 - 5 } & $>30$ & 4 & $6.1 \%$ \\
\hline \multirow{5}{*}{ Size } & $<500$ & 4 & $6.1 \%$ \\
\cline { 2 - 5 } & $500-2000$ & 21 & $31.8 \%$ \\
\cline { 2 - 5 } & $2001-5000$ & 22 & $33.3 \%$ \\
\cline { 2 - 5 } & $5001-10000$ & 12 & $18.2 \%$ \\
\cline { 2 - 4 } & $>10000$ & 7 & $10.6 \%$ \\
\hline Total & & 66 & $100 \%$ \\
\hline
\end{tabular}

365

It should be noted that in this study, the data of variables came from the annual reports of 66 companies in China's clean energy industry in 2013 and 2014, all the 66 listed entrepreneurial companies in clean energy industry had received GSB and GSA, while in which there were 8 companies that did not report the data about R\&D invest in their annual report. Therefore, this study deleted these 8 companies from samples.

\subsection{Variables definitions and operationalization}

In this study, dependent variable is defined as entrepreneurial companies' growth (ECG), independent variable refers to R\&D investment, and moderating variables include GSB and GSA. In addition to these, the study also considered some control variables. They are as follows.

\subsubsection{Entrepreneurial companies' growth (ECG)}

Companies' growth can be measured by multiple indexes, and companies of different types and in different development periods present different growth characteristics (McKelvie and Wiklund, 2010). The entrepreneurial companies' growth embodied in launching competitive products and service (Naldi and Davidsson, 2014; Shao et al., 2016), and the increasing of products' sale and employees' number (Coad, et al., 2016). It should be noted that companies' growth should be measured by one index that specifically indicating their development (Davidsson et al., 2010). In the samples, these companies' business covered some other industries in addition to clean energy industry. Therefore, to measure entrepreneurial companies' growth more directly, this study defines the income of main business (namely the business about clean energy) as entrepreneurial companies' growth (Tibor et al., 2015).

\subsubsection{R\&D investment (R\&D)}


The R\&D investment involved in the whole process of products innovation, including the initial systematic planning and scale production in the later stage (Honoré et al., 2015). Companies' R\&D investment, accompanied by high uncertainty and high risk, needed comparatively long time to generate its influence. As a result, R\&D investment was often considered as the organizational searching behaviour (O'Brien and David, 2014). The aim of the R\&D investment was to provide innovative solution schemes and produce new knowledge and technologies (Lee, et al., 2014). The process of R\&D investment was quite complicated, including the creation and dissemination of new knowledge, the application of new technologies (Wang, 2010) etc. Based on the analysis above, companies' R\&D activities can be defined as the organizational searching behaviours aiming at solving the practical problems and nurturing the core competitiveness (Lewellyn and Bao, 2015). It should be mentioned that R\&D included basic research, applied research, and experimental development. In this study, the variables to measure clean manufacturing entrepreneurial companies' $R \& D$ investment included $R \& D_{t}$ and $R \& D_{t-1}$, in which $R \& D_{t}$ was used to measure the present clean manufacturing $R \& D$ investment and $R \& D_{t-1}$ was used to measure the clean manufacturing $R \& D$ investment in previous year, namely the lag effect of $R \& D$ investment.

\subsubsection{GSB and GSA}

Government subsidies were very important tools for signal transmission (Kleer, 2010; Lerner, 1999). Through direction guiding, they increased firms' possibilities of achieving external funding (Meuleman and De Maeseneire, 2012; Feldman and Kelley, 2006), accelerating commercialization and promoting entrepreneurial companies' growth. Through sharing the risk and cost of R\&D with firms, they enhanced firms' motivation and confidence in R\&D, promoting effective development of entrepreneurial companies (Huang et al., 2008). According to the order of subsidies been distributed, government subsidies can be divided into two different forms: GSB and GSA. At present, their accurate definitions have not been given by scholars yet. In this study, GSB referred to supporting method that government decided the subsidies amount beforehand and appropriated the subsidies as soon as the projects started. GSA refer to the supporting method that government departments appropriate certain proportional reimbursement when the projects achieve anticipated achievement or after the projects have been finished. As government subsidies influence entrepreneurial companies' growth and R\&D, it is logical to say the two moderating variables i.e. GSB and GSA have certain influences on entrepreneurial companies' growth and R\&D. In terms of data selection, this study used the company annual report to distinguish between GSB and GSA in accounting standards. The accounting standards considered that GSB should be included in deferred income, and GSA should be included in the current profit and loss. Therefore, in actual data calculation, GSB, GSA and R\&D did not have the problem of repeated computation and collinearity.

\subsubsection{Control variables}


426

427

428

429

430

431

432

433

434

435

436

437

438

439

440

441

442

443

444

445

446

447

448

449

450

451

452

453

454

455

456

457

458

459

460

461

462

Entrepreneurial companies in high-tech industry are accompanied by high profit and high risk during their growth period (Bertoni et al., 2015; Grilli and Murtinu, 2014)., Jin et al (2016) found that compared with companies in the traditional industry, the growth of entrepreneurial companies in high-tech industry were constricted by many factors, which were always decided by their industrial classifications. In this paper, the selected 58 clean energy companies were all high-tech entrepreneurial companies and referred to different clean energy industries, including wind power industry, water and electricity industry, nuclear power industry and so on. Therefore, this study chose industrial classification (IC) as one of the control variables.

The growth of entrepreneurial companies with different ages presents different characteristics. During the start-up stage, entrepreneurial companies focused on building the system suitable for their development as they lacked the resources base and the financial channel (Khelil, 2016). During the mature stage, the entrepreneurial companies focused on modifying their management framework to meet the requirements of R\&D activities (Khelil, 2016). During the decline stage, the main factors that influence the growth of entrepreneurial companies include the market potential of key technologies, and the risk of entering the capital market (Reijonen et al., 2015; Kautonen et al., 2015). Generally speaking, entrepreneurial companies with different ages differ greatly in core competitiveness, technological innovation ability, management system, property relations etc. (Bao and Peng, 2016; Shan et al., 2016), so the growth of these companies presented different characteristics. All in all, the age of entrepreneurial companies influences their growth. As a result, in this study, age is also treated as a control variable.

For entrepreneurial companies in high-tech industry, the size of the talent was one of the key factors influencing their growth (Laufs and Schwens, 2014; Puente et al., 2015). From the perspective of entrepreneurial companies' production cost, Trianni et al. (2016) pointed out that large size helped firms to reduce production cost and achieve organizational resources. Generally speaking, companies' size positively influences their R\&D activities, which in turn speed up companies' development (Ahmedova, 2015). Through statistical analysis of companies in a number of countries, like America, Britain etc., Meath et al. (2016) found that large companies (the number of employees is more than 1000 ) consumed $80 \%$ $97 \%$ of total R\&D investment. In summary, companies' size was one of the important factors that influenced entrepreneurial companies' growth. To be specific, the larger the companies are, the lower the cost of the R\&D activities. Similar as the research done by Vaona and Pianta (2008), in this study, size is also treated as a control variable.

\subsection{Methodology}

Multi-regression models have been widely used to explore the statistical problems in society management (Yu et al., 2016). For example, Acaroĝlu and Aydoĝan (2012) applied the Multi- 
463

464

465

466

467

468

469

470

471

472

473

474

475

476

477

478

479

480

481

482

483

484

485

486

487

488

489

490

491

492

493

494

495

496

497

498

499

regression models to analyse the factors that affect health-related quality of life in adult spinal deformity. Amiri et al. (2015) utilized the Multi-regression models to develop energy consumption indicators for commercial buildings. Multi-regression models were regarded as very powerful tools as they allowed the users to explore the effects of a changing variable on the dependent variable while holding other variables constant in certain degree (Smith and Smith, 2015). To be specific, the multi-regression models helped the researchers and the readers to deepen their understanding of the qualitative analysis, and helped them to reveal the dependence relationship among the variables based on which the researchers can find the internal relationships among the variables. The purpose of this research is to explore how GSB and GSA promote entrepreneurial companies' growth, so it is reasonable and scientifically correct to utilize the multi-regression models to carry out this research.

\section{Results}

Because the data of the GSB, BSA, R\&D investment, and the main business income of the 59 entrepreneurial companies in clean energy industries was different orders of magnitude, and the data did not meet the normal distribution, so it is not suitable for direct regression analysis. In the actual data processing, all the variables were logarithmic processed. In addition, to avoid the existence of the common linear problem, the independent variable and adjustment variable have been processed centralization. Descriptive statistics for the control variables, dependent variables, moderating variables and independent variables in the models were reported in Table 3 (see appendix 1). In Table 3, the normal distribution was checked by the 1-Sample K-S command, and all variables of $P>0.05$, which can be considered that variables are similar to the normal distribution and suitable for regression model analysis. It can be seen in Table 4, the ECG in 2014 was significantly related with size $(r=0.828, p<0.001), R \& D$ investment in 2012, 2013 and 2014 ( $r=0.703, p<0.001 ; r=0.693$, $p<0.001 ; r=0.745, p<0.001)$, GSB and GSA in $2014(r=0.621, p<0.001 ; r=0.684, p<0.001)$.

To explore how GSB and GSA influenced the relationship between R\&D investment and entrepreneurial companies' growth, this study constructed multi-regression models to verify the related hypotheses. This study adopted the widely applied 4 steps to test the moderating effects. The results of the hierarchical moderated regression analysis were presented in Table 4.

In model 1 , the study only considered the control variables and found that ECG has highly positively relevance with the size $(\beta=0.824, p<0.001)$.

In model 2, the study entered the independent variables. On the basis of eliminating the rate of market growth, this study found that the R\&D investment in 2012 and R\&D investment in 2013 were not significantly positive with entrepreneurial companies' growth in $2014(\beta=0.287, p>0.1 ; \beta=-0.150, p>0.1)$, while the R\&D investment in 2014 was 
500 significantly positive with entrepreneurial companies' growth in 2014 ( $\beta=0.273, p<0.05$ ).

501 Therefore, $\mathrm{H} 1$ was not supported.

502 In model 3, the study included the moderator variables found that GSB and GSA in 2014

503 were unrelated to ECG $(\beta=0.109, p>0.1 ; \beta=0.033, p>0.1)$.

504 In model 4, the study added the interaction of R\&D expenditure with GSB and GSA in 2014.

505 The regression results showed that the regression coefficients of the regulating variables

506 GSB and GSA and the interaction items to ECG were all significant at the level of $P<0.05$,

507 which shown that GSB and GSA have a significant adjustment between R\&D expenditure and

508 ECG, and found the moderating effect of GSB on the relationships between R\&D2014 and

509 ECG was negatively significant $(\beta=-0.360, p<0.05), \mathrm{H} 2$ was not supported. In model 4 , the

510 study also found that the moderating effect of GSA on the relationships between R\&D2014

511 and ECG was positively significant $(\beta=-0.444, p<0.01)$, thus, $H 3$ was supported.

512 The interaction plot was widely used to describe the moderating effects (Aiken and West,

513 1991), which was shown as Fig. 2. As to the interaction of R\&D investment (R\&D) with

514 government subsidies beforehand (GSB), the results indicate that R\&D was negatively

515 related with entrepreneurial companies' growth (ECG) when GSB was one standard

516 deviation above the mean, but positively related with ECG when GSB was one standard

517 deviation below the mean.

518 With regard to the interaction of R\&D with GSA, the results shown that R\&D was 519 positively related with ECG when GSA was one standard deviation above the mean, while 520 negatively related with ECG when GSA was one standard deviation below the mean.

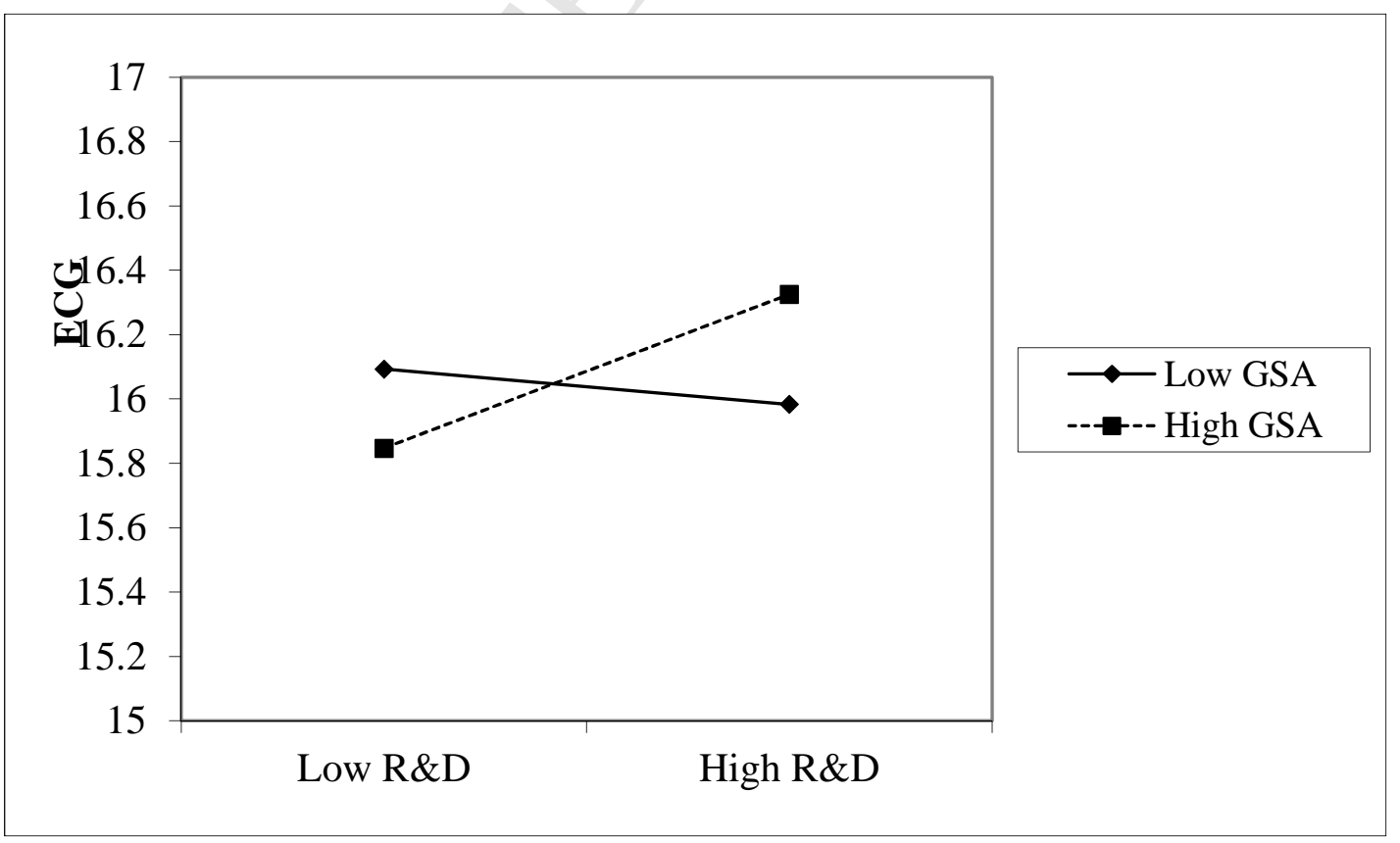




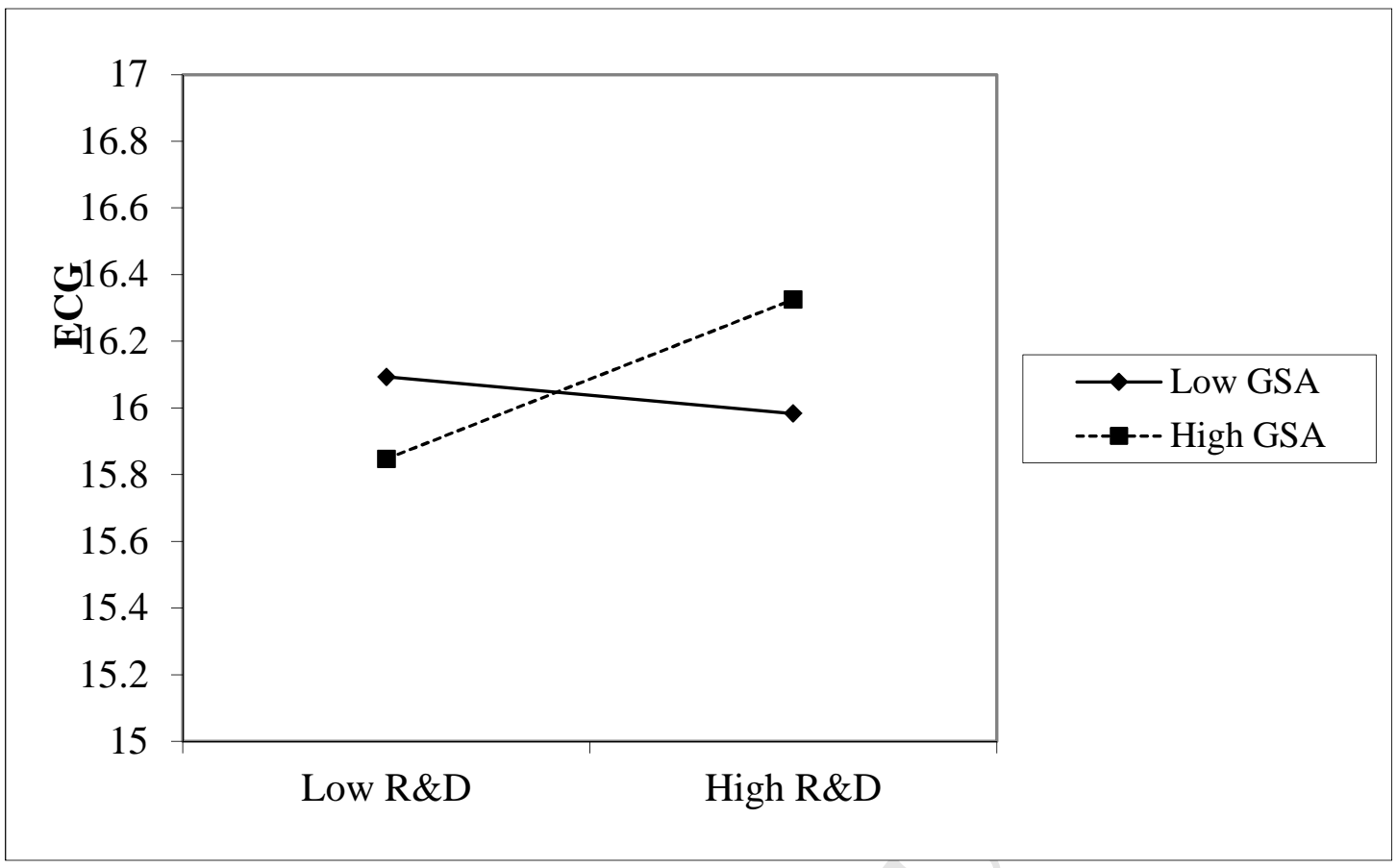

Fig.2. Moderating effects of GSB and GSA on the relationship between R\&D and ECG

\section{Discussion and Conclusions}

526 The research focused on how entrepreneurial companies' R\&D investment influences their

527 growth, especially the moderating effects of GSB and GSA by taking the listed companies in 528 clean energy industries as the samples. The findings shown that R\&D investment did not 529 have lag effect on entrepreneurial companies' growth, GSB have negatively positive 530 moderating effects on the relationship between R\&D investment and entrepreneurial 531 companies' growth, and GSA have positive moderating effects on the relationship between 532 R\&D investment and entrepreneurial companies' growth.

\section{$533 \quad 6.1$ Discussion}

534 For $\mathrm{H} 1$ that the investment in R\&D has a lag effect on entrepreneurial companies' growth 535 has not been validated in this study, which is different from the opinions of Fitzpatrick 536 (2008), Rosenberg (1990), Luintel and Khan (2011), Campbell (2012) et al. By using specific 537 cases analysis, they found that the outputs of R\&D have the time-lag effect. Specifically, 538 Fitzpatrick (2008) found that the application of basic research in clinical practice normally 539 required 10 to 30 years, sometimes even longer. A good example in sight was personalized 540 cancer drug as it spent nearly 50 years from research to practical application (Yarden and 541 Caldes, 2013). Through empirical research, Yun et al. (2008) found that there was a time lag 542 of 4 years between the indexes of patent impact and rate of return on common stockholders' 543 equity (ROE), and 5 years of time lag with earnings per share (EPS), and lag time in the 
544 pharmaceutical area was even longer. Moreover, Campbell (2012) pointed out that there 545 was a time lag between entrepreneurial enterprises' performance and their new process

546 development (adopting IT and increasing the investment in IT). To be more specific, it spent

5473 to 4 years to achieve maximum performance advantage of investment in IT on average.

548 From the analysis above, this study found that the time-lag effect of the outputs of R\&D was

549 very common. While for the entrepreneurial companies in clean industry in China, the time-

550 lag effect of investment in R\&D was not so obvious. Firstly, entrepreneurial companies

551 lacked the legitimacy in the eyes of resources providers and consumers (Zhang and White,

552 2016), so it is highly possible that they think the quality and market of the entrepreneurial

553 companies' new products cannot be guaranteed. To satisfy the need for the return of 554 investment (ROI) of shareholders, it is necessary for the R\&D activities to produce the 555 instant effects. Therefore, most R\&D investment was involved in applied research or 556 experiment research while not basic research, therefore the output of the R\&D investment 557 in clean energy industries are relatively direct and obvious. Secondly, the entrepreneurial 558 companies in clean energy industries in China were very large and have rich experience in 559 marketing and technology innovation. Therefore, they probably can absorb the extensive, 560 detailed and structural marketing information (Fabienne and Eric, 2012), then utilize the 561 outputs of R\&D instantly. Thirdly, the length of lag-time of R\&D activities was decided by the 562 gap between research investment and academic achievement (Jaekyung et al., 2011), the 563 relatedness between new products, new processes and R\&D outputs, and lag effect 564 between academic investment and industrial utilization of R\&D achievement (Mansfield, 565 1991). In this research, a large number of R\&D investments mainly focused on equipment 566 innovation, which was near to the final market and easy to be industrialized. In addition to 567 this, the gap and uncertainty of entrepreneurial companies' R\&D activities in the clean 568 energy industries in China can be reduced by government procurement. Therefore, the lag 569 effect of R\&D investment cannot be found in this research. According to this conclusion, it is 570 suggested that the government participate in the process of R\&D innovation in the form of 571 subsidies (including GSA and GSB), increasing the R\&D investment of entrepreneurial 572 enterprises in the field of clean energy, enhancing enterprise innovation ability and 573 enriching enterprise entrepreneurial resources (Oliviero, 2011). The development of clean 574 energy was greatly encouraged by the formulation of appropriate GSA and GSB policies and 575 the implementation. Subsidy investment can not only reduce the pressure of R\&D and 576 innovation of clean energy, but also send a positive signal to the market (Maryann and 577 Maryellen, 2006), so that clean energy start-ups can get more investment channels to 578 expand the scale of production.

579 For H2, contrary to the opinions of Meuleman and De Maeseneire (2012), Feldman and 580 Kelley (2006), this study found that GSB have negative moderating effects on the 581 relationship between R\&D investment and entrepreneurial companies' growth. GSB shared 582 the R\&D failure risk with entrepreneurial companies, helping to partially alleviate the market 
583 failure (Lee and Cin, 2010). However, it is highly possible that the GSB crowed out the

584

585

586

587

588

589

590

591

592

593

594

595

596

597

598

599

600

601

602

603

604

605

606

607

608

609

610

611

612

613

614

615

616

617

618

619

620

621

companies' own R\&D expenditure (Li, 2002). As a result, entrepreneurial companies' R\&D activities will be influenced by the government greatly. At this time, it is not easy for the products and technologies originated from these R\&D activities to meet the customers' need since the main guidelines for entrepreneurial companies' R\&D should be the market and customers. Without the profitable products, the entrepreneurial companies cannot survive in the fierce market competition, let alone the rapid growth and development. Meanwhile, GSB can be regarded as important tools for signal transmission (Kleer, 2010; Lerner, 1999).

When the amount of GSB for R\&D was considerable high, entrepreneurial companies will spend much more energy and resources to develop and maintain the strong guanxi network with the government departments. It means that to a certain degree, the entrepreneurial companies will neglect to develop the weak guanxi networks with other stakeholders. These weak guanxi networks expanded entrepreneurial companies' access to diversified resources, excavate existing resources potentialities and enhance organizational management (Ahuja et al., 2009), which can promote entrepreneurial companies' growth greatly. In summary, the GSB for R\&D reduced entrepreneurial companies' motivation to exploit the weak guanxi network, therefore impeding entrepreneurial companies' growth. Lastly, the more advance subsidies the government appropriates to the entrepreneurial companies, the more expensive the technologies and products shall be. Correspondingly, the initial costs for these renewable energy technologies and the related products will be relatively higher (Hirmer and Cruickshank, 2014). Most customers tend to put high priority on the initial cost (Reddy and Painuly, 2004), so it is not easy for them to spend a lot of money on these renewable energy technologies and the related products. Therefore, GSB have negative moderating effects on the relationship between R\&D investment and entrepreneurial companies' growth. According to this conclusion, it is suggested that the government should reduce the proportion of GSA as much as possible by providing subsidies to enterprises. In general, there was a certain moral hazard in GSA, and it cannot play its due role in improving the R\&D efforts of enterprises. Compared with the GSB, GSA WAs a kind of low efficiency policy. However, due to the fact that the definition of GSA was difficult to measure, GSA was still a common policy tool in practice. Especially for the R\&D projects with strong credit capital constraints, GSA has a certain starting and guiding role (Hussinger, 2008). Therefore, it is suggested that GSA as a supplementary policy tool can reduce the negative impact of government subsidies on the growth of entrepreneurial enterprises, and promote more attention to clean energy related R\&D and product innovation (Craig and Allen 2014).

Normally, the negative effect of GSB on clean energy companies' growth came from the following aspects. It is very possible for GSB to distort clean energy companies' growth investment and R\&D activities, because the government enforced their oriented objectives and will focus on clean energy companies which go against those companies' development strategies (Haas et al., 2004). Large amount of GSB made the competition in clean energy 
622

623

624

625

626

627

628

629

630

631

632

633

634

635

636

637

638

639

640

641

642

643

644

645

646

647

648

649

650

651

652

653

654

655

656

657

658

659

industry much fiercer, and engages many large state-owned enterprises enter the industry, while they did not master the key technology and process, even making high pollution and low output (Shen and Luo, 2015). Chen and Luo also pointed out that large amount of government subsidies has induced solar companies to expand production and resulted in the risk of solar companies' overcapacity. With regards to why GSB has negative effect on the relationship between clean energy companies' R\&D investment and growth, it is referred to clean energy companies' owner ship and industry types (Yu et al., 2016; Arias and beers, 2013). The amount and ways of GSB should be adjusted according to the clean energy companies' owner ship and industry types, while not the more, the better. The influence of GSB was also decided by the duration of subsidies. Generally speaking, the performance of clean energy companies which have been supported by GSB will be improved in the first year, but the subsequent performance will be decided by clean energy companies' ownership and political relationship (Zhang et al., 2016).

For H3, GSA have positive moderating effects on the relationship between R\&D investment and entrepreneurial companies' growth, which is similar with the views of Levy and Terleckyj (1983), Lichtenberg (1984), Mansfield and Switzer (1985) and Katrak (1998), Ouyang and Lin (2014), U.S. DOE Energy Information Administration (2013), Silveira et al. (2013), Chang et al. (2013). The main characteristics of entrepreneurial companies were mainly embodied in four dimensions, namely proactiveness, innovativeness, aggressive competitiveness, and risk taking (Zehir et al., 2015). When the entrepreneurial companies first enter the market, it is quite difficult to achieve the key resources as they are not legitimated in the eyes of many resources providers (Zhang and White, 2016). Constrained by the limited resources, the new technologies and products originated from entrepreneurial companies were usually the improved techniques, systems and services. If the entrepreneurial companies obtained a large amount of GSA, this probably will make them believe in their products and technologies in the future. In summary, the GSA for entrepreneurial companies' R\&D activities probably led entrepreneurial companies' strategic orientations, promoting their sustainable development. Moreover, the manufacturing process of the clean energy products often demands many processes and each process requires capital-intensive equipment (Ockwell et al., 2007). Many potential customers in the market for the clean energy technologies and related products have no or little knowledge and experience for the application of these technologies and related products (Flamos et al., 2008). Customers' poor access to the information of clean energy technologies and the related products was one of the most important barriers for these products to realize their market value (Luthra et al., 2015). From this point, GSA were helpful to bring the passion for innovation, exploit the potential market and enhance the confidence of customers.

As to the entrepreneurial companies in the clean energy industries, the positive function of government subsidies can also be realized. Prior studies have proved the GSA will alter the 
660

661

662

663

664

665

666

667

668

669

670

671

672

673

674

675

676

677

678

679

680

681

682

683

684

685

686

687

688

689

690

691

692

693

694

695

696

development phase of clean energy companies (Costa-Campi et al., 2014) and Zhang et al. (2016) further proved that GSA have different effects on clean energy companies' R\&D investment during different periods. GSA encouraged these entrepreneurial companies to broken through the threshold in certain growth period. Although Simpson and Clifton (2016) found that large amount of GSA was harmful to the enthusiasm of clean energy companies' original innovation and revolutionary product innovation, even some clean energy companies apply for GSA by means of rent seeking to compensate for their own investment on R\&D activities (Darmani et al., 2016), such kind of R\&D investment are not real innovative activities. Along with the policy about GSA in clean energy industries becomes increasingly regulatory and the supervisory process about GSA in clean energy industries becomes more and more strict, GSA will have normative function. According to this conclusion, it is suggested that the government give priority to GSB by providing subsidies to enterprises. After a clearer definition of GSB, it should give priority to the GSB, make reasonable use of GSB to internalization the R\&D spillover effect of enterprises, and generate the greatest incentive effect (Lach, 2000) to avoid blind and inefficient subsidies. The government needed to strengthen supervision in the event of GSB, especially for the technology research and development results of new ventures in the clean energy industry, so that the purpose of enterprise GSB was transparent, the direction of the use of subsidy funds was clear, and the information asymmetry between government and enterprises was reduced (Kleer, 2010), in order to prevent enterprises violating the intention of government subsidies for clean energy to change the use of funds.

\subsection{Research implication}

This research comprehensively discusses the function of GSB and GSA on entrepreneurial companies' growth at the same time based on the same samples in similar industries. Therefore, this research contributes to understanding the relationship between government subsidies and entrepreneurial companies' development, and exploring the differences between GSB and GSA, which promote entrepreneurial companies' development.

The theoretical value of the study is to provide a theoretical logic for explaining the field of clean energy subsidies (including GSA and GSB) how to influence the growth of entrepreneurial enterprises, and also analyse GSA and GSB on the growth of the enterprise.

Based on the above analysis, practical management implications can be concluded as follows. (a) Seen from the perspectives of government, it should exert the economic orientation functions and provide scientific and rational subsidy standards for the industry with a good development prospect. Subsidy programs should also be strictly assessed to promote the harmonious development of the industrial structure. The government should take the realistic condition of economic development as the basis and help firms to progress with sufficient guidance and supervision. (b) For firms, they should be oriented to market, and 
697 take full advantage of government preferential policies. In addition, they should also save

698 the costs, innovate new products and make rational resource allocation, thus achieving the

699 long-term sustainable development. Moreover, firms must get a clear self-localization

700 analysis and a clear understanding of the starting point and the direction of GSA. Only when

701 government subsidies meet firms' own pursuits, a win-win situation can be achieved.

702 Otherwise, it wastes resources and even may cause firms' exit from the market competition.

$703 \quad 6.3$ Limitations and future research

704 This study only chose 3 years' data in certain industry (clean energy industry) to test the 705 hypotheses about R\&D, GSB, GSA and ECG. The samples are also limited. Obviously, it will 706 also influence the judgement on the function of government subsidies to influence the 707 relationship between R\&D and entrepreneurial companies' growth. Therefore, in the future 708 research, it is better for us to trace these samples and select more time series data to test 709 the model in this research again.

710

711 Acknowledgements

712 This research is supported by the Fundamental Research Funds for the Central Universities 713 (2016VI018). 


\section{References}

Acaroĝlu, M., Aydoĝan, H., 2012. Biofuels energy sources and future of biofuels energy in Turkey. Biomass and Bioenergy 36, 69-76. doi:10.1016/j.biombioe.2011.10.004

Acemoglu D.,Aghion P,Bursztyn L,et al. The Environment and Directed Technical Change. American Economic Review,2012,102(1) : 131-166

Ahmedova, S., 2015. Factors for Increasing the Competitiveness of Small and Medium- Sized Enterprises (SMEs) in Bulgaria. Procedia - Soc. Behav. Sci. 195, 1104-1112. doi:10.1016/j.sbspro.2015.06.155

Ahuja, G., Polidoro, F., Mitchell, W., 2009. Structural homophily or social asymmetry? the formation of alliances by poorly embedded firms. Strateg. Manag. J. 30, 941-958. doi:10.1002/smj.774

Aiken, L.S., West, S.G., 1991. Multiple regression: Testin and interpreting interactions, Multiple regression: Testing and interpreting interactions.

Albino, V., Ardito, L., Dangelico, R. M., \& Petruzzelli, A. M.,2014. Understanding the development trends of low-carbon energy technologies: a patent analysis $\hat{i}$. Applied Energy, 135(C), 836-854.

Alexander, R.M., Organ, A.J., 2015. Business tax incentives. Bus. Horiz. 58, 363-369. doi:10.1016/j.bushor.2015.03.001

Almus, M., Czarnitzki, D., 2003. The Effects of Public R\&D Subsidies on Firms' Innovation Activities. J. Bus. Econ. Stat. 21, 226-236. doi:10.1198/073500103288618918

Amiri, S.S., Mottahedi, M., Asadi, S., 2015. Using multiple regression analysis to develop energy consumption indicators for commercial buildings in the U.S. Energy Build. 109, 209-216. doi:10.1016/j.enbuild.2015.09.073

Antonelli, C., Crespi, F., 2013. The "Matthew effect" in R and D public subsidies: The Italian evidence. Technol. Forecast. Soc. Change 80, 1523-1534. doi:10.1016/j.techfore.2013.03.008

Artz, K.W., Norman, P.M., Hatfield, D.E., Cardinal, L.B., 2010. A longitudinal study of the impact of R\&D, patents, and product innovation on firm performance. J. Prod. Innov. Manag. 27, 725-740. doi:10.1111/j.1540-5885.2010.00747.x

Azzimonti, M., de Francisco, E., Krusell, P., 2008. Production subsidies and redistribution. J. Econ. Theory 142, 73-99. doi:10.1016/j.jet.2007.03.009

Bao, H., Peng, Y., 2016. Effect of land expropriation on land-lost farmers' entrepreneurial action: A case study of Zhejiang Province. Habitat Int. 53, 342-349. doi:10.1016/j.habitatint.2015.12.008

Batlle, C. ,2011. A method for allocating renewable energy source subsidies among final energy consumers. Energy Policy, 39(5), 2586-2595.

Beason, R., Weinstein, D.E., 1996. Growth, Economies of Scale, and Targeting in Japan (19551990). Rev. Econ. Stat. 78, 286-295. doi:10.2307/2109930

Berrone, P., Gertel, H., Giuliodori, R., Bernard, L., Meiners, E., 2014. Determinants of Performance in Microenterprises: Preliminary Evidence from Argentina. J. Small Bus. Manag. 52, 477-500. doi:10.1111/jsbm.12045

Bertoni, F., Croce, A., Guerini, M., 2015. Venture capital and the investment curve of young high-tech companies. J. Corp. Financ. 35, 159-176. doi:10.1016/j.jcorpfin.2015.08.012 
Bontempi, M.E., Prodi, G., 2009. Entry strategies into China: The choice between Joint Ventures and Wholly Foreign-Owned Enterprises. An application to the Italian manufacturing sector. Int. Rev. Econ. Financ. 18, 11-19. doi:10.1016/j.iref.2008.02.007

Brinckmann, J., Salomo, S., Gemuenden, H.G., 2011. Financial Management Competence of Founding Teams and Growth of New Technology-Based Firms. Entrep. Theory Pract. 35, 217-243. doi:10.1111/j.1540-6520.2009.00362.x

Bronzini, R., Piselli, P., 2016. The impact of R\&D subsidies on firm innovation. Res. Policy 45, 442-457. doi:10.1016/j.respol.2015.10.008

Campbell, M., 2012. WHAT A DIFFERENCE A YEAR MAKES: TIME LAG EFFECT OF INFORMATION TECHNOLOGY INVESTMENT ON FIRM PERFORMANCE. J. Organ. Comput. Electron. Commer. 22, 237-255. doi:10.1080/10919392.2012.696944

Chang, P.L., Ho, S.P., Hsu, C.W., 2013. Dynamic simulation of government subsidy policy effects on solar water heaters installation in Taiwan. Renew. Sustain. Energy Rev. 20, 385-396. doi:10.1016/j.rser.2012.12.009

Claro, S., 2006. Supporting inefficient firms with capital subsidies: China and Germany in the 1990s. J. Comp. Econ. 34, 377-401. doi:10.1016/j.jce.2005.12.001

Clarysse, B., Wright, M., \& Mustar, P. ,2009. Behavioural additionality of r\&d subsidies: a learning perspective. Research Policy, 38(10), 1517-1533

Clausen, T.H., 2009. Do subsidies have positive impacts on R\&amp;D and innovation activities at the firm level? Struct. Chang. Econ. Dyn. 20, 239-253. doi:http://dx.doi.org/10.1016/j.strueco.2009.09.004

Coad, A., Rao, R., 2008. Innovation and firm growth in high-tech sectors: A quantile regression approach. Res. Policy 37, 633-648. doi:10.1016/j.respol.2008.01.003

Coad, A., Segarra, A., Teruel, M., 2016. Innovation and firm growth: Does firm age play a role? Res. Policy 45, 387-400. doi:10.1016/j.respol.2015.10.015

Colombo, M.G., Grilli, L., Murtinu, S., Piscitello, L., Piva, E., 2009. Effects of International R\&D Alliances on Performance of High-Tech Start-Ups: a Longitudinal Analysis. Strateg. Entrep. J. 3, 346-368. doi:10.1002/sej.78

Costa-Campi, M.T., Duch-Brown, N., García-Quevedo, J., 2014. R\&D drivers and obstacles to innovation in the energy industry. Energy Econ. 46, 20-30. doi:10.1016/j.eneco.2014.09.003

Craig, C. A., \& Allen, M. W. ,2014. Enhanced understanding of energy ratepayers: factors influencing perceptions of government energy efficiency subsidies and utility alternative energy use. Energy Policy, 66(2), 224-233.

Czarnitzki, D., Kraft, K., 2004. An empirical test of the asymmetric models on innovative activity: Who invests more into R\&D, the incumbent or the challenger? J. Econ. Behav. Organ. 54, 153-173. doi:10.1016/j.jebo.2003.01.008

Dai, X., Cheng, L., 2015. The effect of public subsidies on corporate R\&D investment: An application of the generalized propensity score. Technol. Forecast. Soc. Change 90, 410-419. doi:10.1016/j.techfore.2014.04.014

Darmani, A., Arvidsson, N., Hidalgo, A., 2016. Do the strategic decisions of multinational energy companies differ in divergent market contexts? An exploratory study. Energy Res. Soc. Sci. 11, 9-18. doi:10.1016/j.erss.2015.08.009

Dever, P. ,2010. Reforming subsidies in the federal budget. Politics \& Policy, 36(5), 854-878.

Davidsson, P., Achtenhagen, L., Naldi, L., 2010. Small Firm Growth. Found. Trends Entrep. 6, 69-166. doi:10.1561/0300000029 
Desai, M.A., Hines, J.R., 2008. Market reactions to export subsidies. J. Int. Econ. 74, 459-474. doi:10.1016/j.jinteco.2007.04.006

Diaz Arias, A., van Beers, C., 2013. Energy subsidies, structure of electricity prices and technological change of energy use. Energy Econ. 40, 495-502. doi:10.1016/j.eneco.2013.08.002

Du, J., Mickiewicz, T., 2016. Subsidies, rent seeking and performance: Being young, small or private in China. J. Bus. Ventur. 31, 22-38. doi:10.1016/j.jbusvent.2015.09.001

Dzhumashev, R., Mishra, V., Smyth, R., 2016. Exporting, R\&D investment and firm survival in the Indian IT sector. J. Asian Econ. 42, 1-19. doi:10.1016/j.asieco.2015.10.002

Eveleens, C., 2010. Innovation management; a literature review of innovation process models and their implications. Science (80-. ). 1-16.

Fabienne, F., Eric, G., 2012. An Analysis of the Offshoring Decision Process: The Influence of the Company's Size. Procedia - Soc. Behav. Sci. 58, 596-605. doi:10.1016/j.sbspro.2012.09.1037

Feldman, M.P., Kelley, M.R., 2006. The ex ante assessment of knowledge spillovers: Government R\&D policy, economic incentives and private firm behavior. Res. Policy 35, 1509-1521. doi:10.1016/j.respol.2006.09.019

Felzensztein, C., Gimmon, E., Aqueveque, C., 2013. Entrepreneurship at the Periphery: Exploring Framework Conditions in Core and Peripheral Locations. Entrep. Theory Pract. 37, 815-835. doi:10.1111/j.1540-6520.2012.00515.x

Feng, X., Johansson, A.C., Zhang, T., 2015. Mixing business with politics: Political participation by entrepreneurs in China. J. Bank. Financ. 59, 220-235. doi:10.1016/j.jbankfin.2015.06.009

Fitzpatrick, J.J., 2008. Lag time in research to practice: are we reducing or increasing the gap? Appl. Nurs. Res. 21, 1. doi:10.1016/j.apnr.2007.10.001

Flamos, A., Van der Gaast, W., Doukas, H., Deng, G., 2008. EU and Asian countries policies and programmes for the diffusion of sustainable energy technologies. Asia Eur. J. 6, 261-276. doi:10.1007/s10308-008-0177-z

Girma, S., Görg, H., Strobl, E. ,2007. The effect of government grants on plant level productivity is. Economics Letters, 94(3), 439-444.

Girma, S., Gong, Y., Görg, H., Yu, Z., 2009. Can production subsidies explain China's export performance? Evidence from firm-level data. Scand. J. Econ. 111, 863-891. doi:10.1111/j.1467-9442.2009.01586.x

GÖRg, H., Strobl, E., 2007. The Effect of R\&D Subsidies on Private R\&D. Economica 74, 215234. doi:10.1111/j.1468-0335.2006.00547.x

Grilli, L., Murtinu, S., 2014. Government, venture capital and the growth of European hightech entrepreneurial firms. Res. Policy 43, 1523-1543. doi:10.1016/j.respol.2014.04.002

Haas, R., Eichhammer, W., Huber, C., Langniss, O., Lorenzoni, A., Madlener, R., Menanteau, P., Morthorst, P.E., Martins, A., Oniszk, A., Schleich, J., Smith, A., Vass, Z., Verbruggen, A., 2004. How to promote renewable energy systems successfully and effectively. Energy Policy 32, 833-839. doi:10.1016/S0301-4215(02)00337-3

Hirmer, S., Cruickshank, H., 2014. Making the deployment of pico-PV more sustainable along the value chain. Renew. Sustain. Energy Rev. doi:10.1016/j.rser.2013.10.018 
Honoré, F., Munari, F., Van Pottelsberghe De La Potterie, B., 2015. Corporate governance practices and companies' R\&D intensity: Evidence from European countries. Res. Policy 44, 533-543. doi:10.1016/j.respol.2014.10.016

Hsu, F.M., Horng, D.J., Hsueh, C.C., 2009. The effect of government-sponsored R\&D programmes on additionality in recipient firms in Taiwan. Technovation 29, 204-217. doi:10.1016/j.technovation.2008.05.001

Hu, G., Hu, A.G., 2001. Ownership, government R\&D, private R\&D, and productivity in Chinese industry. J. Comp. Econ. 29, 136-157. doi:10.1006/jcec.2000.1704

Huang, C.C., Chu, P.Y., Chiang, Y.H., 2008. A fuzzy AHP application in government-sponsored R\&D project selection. Omega 36, 1038-1052. doi:10.1016/j.omega.2006.05.003

Hud, M., Hussinger, K., 2015. The impact of R\&D subsidies during the crisis. Res. Policy 44, 1844-1855. doi:10.1016/j.respol.2015.06.003

Hussinger, K. ,2008. R\&d and subsidies at the firm level: an application of parametric and semiparametric two-step selection models. Journal of Applied Econometrics, 23(6), 729-747.

Jaekyung, Y., Byung Ho, J., Kangmin, C., 2011. Finding the time lag effect of the R\&amp;D activity for a government research program of Korea, in: Business Innovation and Technology Management (APBITM), 2011 IEEE International Summer Conference of Asia Pacific. pp. 221-225. doi:10.1109/APBITM.2011.5996327

Janssens, G., Zaccour, G., 2014. Strategic price subsidies for new technologies. Automatica 50, 1999-2006. doi:10.1016/j.automatica.2014.05.017

Jin, Y., Zhang, Q., Li, S.P., 2016. Topological properties and community detection of venture capital network: Evidence from China. Phys. A Stat. Mech. its Appl. 442, 300-311. doi:10.1016/j.physa.2015.09.029

Jing, G.U., Hao, C., Xian, Z., 2013. Influence of Psychological and Emotional Factors on the Venture Enterprise Value and the Investment Decision-Making. Procedia Comput. Sci. 17, 919-929. doi:10.1016/j.procs.2013.05.117

Kang, K. N., \& Park, H., 2012. Influence of government r\&d support and inter-firm collaborations on innovation in korean biotechnology smes. Technovation, 32(1), 68-78.

Katrak, H., 1998. Economic analyses of Industrial Research Institutes in developing countries: the Indian experience. Res. Policy 27, 337-347. doi:10.1016/S0048-7333(98)00043-2

Kautonen, T., Hatak, I., Kibler, E., Wainwright, T., 2015. Emergence of entrepreneurial behaviour: The role of age-based self-image. J. Econ. Psychol. 50, 41-51. doi:10.1016/j.joep.2015.07.004

Khelil, N., 2016. The many faces of entrepreneurial failure: Insights from an empirical taxonomy. J. Bus. Ventur. 31, 72-94. doi:10.1016/j.jbusvent.2015.08.001

Kleer, R., 2010. Government R\&D subsidies as a signal for private investors. Res. Policy 39, 1361-1374. doi:10.1016/j.respol.2010.08.001

Koga, T., 2005. R\&D subsidy and self-financed R\&D: The case of Japanese high-technology start-ups. Small Bus. Econ. 24, 53-62. doi:10.1007/s11187-005-3096-z

Lach, S. ,2000. Do R\&D Subsidies Stimulate or Displace Private R\&D? Evidence from Israel. National Bureau of Economic Research, Inc.

Lahr, H., Mina, A., 2016. Venture capital investments and the technological performance of portfolio firms. Res. Policy 45, 303-318. doi:10.1016/j.respol.2015.10.001 
Laufs, K., Schwens, C., 2014. Foreign market entry mode choice of small and medium-sized enterprises: A systematic review and future research agenda. Int. Bus. Rev. 23, 11091126. doi:10.1016/j.ibusrev.2014.03.006

Lee, C.Y., Wu, H.L., Pao, H.W., 2014. How does R\&D intensity influence firm explorativeness? Evidence of R\&D active firms in four advanced countries. Technovation 34, 582-593. doi:10.1016/j.technovation.2014.05.003

Lee, E., Walker, M., Zeng, C., 2014. Do Chinese government subsidies affect firm value? Accounting, Organ. Soc. 39, 149-169. doi:10.1016/j.aos.2014.02.002

Lee, E.Y., Cin, B.C., 2010. The effect of risk-sharing government subsidy on corporate R\&D investment: Empirical evidence from Korea. Technol. Forecast. Soc. Change 77, 881890. doi:10.1016/j.techfore.2010.01.012

Lerner, J., 1999. The Government as Venture Capitalist: The Long-Run Impact of the SBIR Program. J. Bus. 72, 285-318. doi:10.1086/209616

Levy, D.M., Terleckyj, N.E., 1983. Effects of Government R\{\&\}D on Private R\{\&\}D Investment and Productivity: A Macroeconomic Analysis. Bell J. Econ. 14, 551-561. doi:10.2307/3003656

Lewellyn, K.B., Bao, S. "Rosey," 2015. R\&D investment in the global paper products industry: A behavioral theory of the firm and national culture perspective. J. Int. Manag. 21, 117. doi:10.1016/j.intman.2014.12.001

Li, W., 2002. Entrepreneurship and government subsidies: A general equilibrium analysis. J. Econ. Dyn. Control 26, 1815-1844. doi:10.1016/S0165-1889(01)00011-2

Lichtenberg, F., 1984. The relationship between federal contract R\&D and company R\&D. Am. Econ. Rev. 74, 73-78.

Luintel, K.B., Khan, M., 2011. Basic, applied and experimental knowledge and productivity: Further evidence. Econ. Lett. 111, 71-74. doi:10.1016/j.econlet.2011.01.017

Luthra, S., Kumar, S., Garg, D., Haleem, A., 2015. Barriers to renewable/sustainable energy technologies adoption: Indian perspective. Renew. Sustain. Energy Rev. doi:10.1016/j.rser.2014.08.077

Malen J, Marcus A A. Promoting clean energy technology entrepreneurship: The role of external context[J]. Energy Policy, 2017, 102:7-15.

Mansfield, E., 1991. Academic research and industrial innovation. Res. Policy 20, 1-12. doi:10.1016/0048-7333(91)90080-A

Mansfield, E., Switzer, L., 1985. How Effective Are Canada's Direct Tax Incentives for R and D? Can. Public Policy / Anal. Polit. 11, 241-246. doi:10.2307/3550705

Maryann P. Feldman, \& Maryellen R. Kelley. ,2006. The ex ante, assessment of knowledge spillovers: government r\&d policy, economic incentives and private firm behavior. Research Policy, 35(10), 1509-1521.

McKelvie, A., Wiklund, J., 2010. Advancing firm growth research: A focus on growth mode instead of growth rate. Entrep. Theory Pract. 34, 261-288. doi:10.1111/j.15406520.2010.00375.x

Meath, C., Linnenluecke, M., Griffiths, A., 2016. Barriers and motivators to the adoption of energy savings measures for small- and medium-sized enterprises (SMEs): The case of the ClimateSmart Business Cluster program. J. Clean. Prod. 112, 3597-3604. doi:10.1016/j.jclepro.2015.08.085

Meuleman, M., De Maeseneire, W., 2012. Do R\&D subsidies affect SMEs' access to external financing? Res. Policy 41, 580-591. doi:10.1016/j.respol.2012.01.001 
Meutia, Ismail, T., 2012. The Development of Entrepreneurial Social Competence and Business Network to Improve Competitive Advantage and Business Performance of Small Medium Sized Enterprises: A Case Study of Batik Industry in Indonesia. Procedia Soc. Behav. Sci. 65, 46-51. doi:10.1016/j.sbspro.2012.11.089

Naldi, L., Davidsson, P., 2014. Entrepreneurial growth: The role of international knowledge acquisition as moderated by firm age. J. Bus. Ventur. 29, 687-703. doi:10.1016/j.jbusvent.2013.08.003

Nitsch, V., 2009. Die another day: Duration in German import trade. Rev. World Econ. 145, 133-154. doi:10.1007/s10290-009-0008-3

O'Brien, J.P., David, P., 2014. Reciprocity and R\&D search: Applying the behavioral theory of the firm to a communitarian context. Strateg. Manag. J. 35, 550-565. doi:10.1002/smj.2105

Ockwell, D., Watson, J., Mackerron, G., 2007. UK - India collaboration to identify the barriers to the transfer of low carbon energy technology. Analysis 124.

Oliviero A. Carboni. ,2011. R\&d subsidies and private $r \& d$ expenditures: evidence from italian manufacturing data. International Review of Applied Economics, 25(4), 419-439.

Ouyang, X., Lin, B., 2014. Impacts of increasing renewable energy subsidies and phasing out fossil fuel subsidies in China. Renew. Sustain. Energy Rev. 37, 933-942. doi:10.1016/j.rser.2014.05.013

Parker, R., 2008. Governance and the entrepreneurial economy: A comparative analysis of three regions. Entrep. Theory Pract. 32, 833-854. doi:10.1111/j.15406520.2008.00258.x

Patzelt, H., Shepherd, D.A., 2009. Strategic entrepreneurship at universities: Academic entrepreneurs' assessment of policy programs. Entrep. Theory Pract. 33, 319-340. doi:10.1111/j.1540-6520.2008.00291.x

Puente, M.C.R., Arozamena, E.R., Evans, S., 2015. Industrial symbiosis opportunities for small and medium sized enterprises: Preliminary study in the Besaya Region (Cantabria, Northern Spain). J. Clean. Prod. 87, 357-374. doi:10.1016/j.jclepro.2014.10.046

Reddy, S., Painuly, J.P., 2004. Diffusion of renewable energy technologies-barriers and stakeholders' perspectives. Renew. Energy 29, 1431-1447. doi:10.1016/j.renene.2003.12.003

Reijonen, H., Hirvonen, S., Nagy, G., Laukkanen, T., Gabrielsson, M., 2015. The impact of entrepreneurial orientation on $\mathrm{B} 2 \mathrm{~B}$ branding and business growth in emerging markets. Ind. Mark. Manag. 51, 35-46. doi:10.1016/j.indmarman.2015.04.016

Rosenberg, N., 1990. Why do firms do basic research (with their own money)? Res. Policy 19, 165-174. doi:10.1016/0048-7333(90)90046-9

Schwartz, G., Clements, B., 1999. Government Subsidies. J. Econ. Surv. 13, 119-148. doi:10.1111/1467-6419.00079

Shan, P., Song, M., Ju, X., 2016. Entrepreneurial orientation and performance: Is innovation speed a missing link? J. Bus. Res. 69, 683-690. doi:10.1016/j.jbusres.2015.08.032

Shao, J., Taisch, M., Mier, M.O., 2017. Influencing factors to facilitate sustainable consumption: from the experts' viewpoints. J. Clean. Prod. 142, 203-216. doi:10.1016/j.jclepro.2015.12.111

Shao, J., Taisch, M., Mier, M.O., 2014. A Proposal of Consumer Driven Framework for Enabling Sustainable Production and Consumption, in: IFIP Advances in Information and Communication Technology. pp. 406-414. doi:10.1007/978-3-662-44736-9_50 
Shao, J., Taisch, M., Ortega-Mier, M., 2016. A grey-DEcision-MAking Trial and Evaluation Laboratory (DEMATEL) analysis on the barriers between environmentally friendly products and consumers: Practitioners' viewpoints on the European automobile industry. J. Clean. Prod. 112, 3185-3194. doi:10.1016/j.jclepro.2015.10.113

Shen, J., Luo, C., 2015. Overall review of renewable energy subsidy policies in China Contradictions of intentions and effects. Renew. Sustain. Energy Rev. doi:10.1016/j.rser.2014.09.007

Silveira, J.L., Tuna, C.E., Lamas, W.D.Q., 2013. The need of subsidy for the implementation of photovoltaic solar energy as supporting of decentralized electrical power generation in Brazil. Renew. Sustain. Energy Rev. 20, 133-141. doi:10.1016/j.rser.2012.11.054

Simón Moya, V., 2015. Young innovative companies (YICs) and entrepreneurship policy. J. Bus. Res. 68, 1432-1435. doi:10.1016/j.jbusres.2015.01.028

Simpson, G., Clifton, J., 2016. Subsidies for residential solar photovoltaic energy systems in Western Australia: Distributional, procedural and outcome justice. Renew. Sustain. Energy Rev. doi:10.1016/j.rser.2016.06.060

Smith, G., Smith, G., 2015. 10 - Multiple Regression, in: Essential Statistics, Regression, and Econometrics. pp. 301-337. doi:10.1016/B978-0-12-803459-0.00010-8

Söderblom, A., Samuelsson, M., Wiklund, J., Sandberg, R., 2015. Inside the black box of outcome additionality: Effects of early-stage government subsidies on resource accumulation and new venture performance. Res. Policy 44, 1501-1512. doi:10.1016/j.respol.2015.05.009

Soininen, J., Martikainen, M., Puumalainen, K., Kyläheiko, K., 2012. Entrepreneurial orientation: Growth and profitability of finnish small- and medium-sized enterprises, in: International Journal of Production Economics. pp. 614-621. doi:10.1016/j.ijpe.2011.05.029

Soratana, K., Harden, C.L., Zaimes, G.G., Rasutis, D., Antaya, C.L., Khanna, V., Landis, A.E., 2014. The role of sustainability and life cycle thinking in U.S. biofuels policies. Energy Policy 75, 316-326. doi:10.1016/j.enpol.2014.10.015

Tibor, T., Edina, K., Laurentiu, D., 2015. Risk and Growth Analysis of Small and Medium Size Enterprises Between 2010 and 2012. Procedia Econ. Financ. 32, 1323-1331. doi:10.1016/S2212-5671(15)01509-9

Trianni, A., Cagno, E., Farné, S., 2016. Barriers, drivers and decision-making process for industrial energy efficiency: A broad study among manufacturing small and mediumsized enterprises. Appl. Energy 162, 1537-1551. doi:10.1016/j.apenergy.2015.02.078

U.S. DOE Energy Information Administration, 2013. Direct Federal Financial Interventions and Subsidies in Energy in Fiscal Year 2010. Energy Inf. Adm.

Vaona, A., Pianta, M., 2008. Firm size and innovation in European manufacturing. Small Bus. Econ. 30, 283-299. doi:10.1007/s11187-006-9043-9

Wang, C.H., Lu, Y.H., Huang, C.W., Lee, J.Y., 2013. R\&D, productivity, and market value: An empirical study from high-technology firms. Omega (United Kingdom) 41, 143-155. doi:10.1016/j.omega.2011.12.011

Wang, E.C., 2010. Determinants of R\&D investment: The Extreme-Bounds-Analysis approach applied to 26 OECD countries. Res. Policy 39, 103-116. doi:10.1016/j.respol.2009.11.010

Wang, F., Zhang, B., 2016. Distributional incidence of green electricity price subsidies in China. Energy Policy 88, 27-38. doi:10.1016/j.enpol.2015.09.035 
Wang, Y., Liu, Y., Liu, K., 2011. Evaluation on the competitiveness of high-tech entrepreneurial enterprises, in: Energy Procedia. pp. 684-689. doi:10.1016/j.egypro.2011.03.121

Wise, S.L., Miles, M.P., 2003. The R\&D Tax Credit And Its Implications For Small Business. J. Appl. Bus. Res. 19, 11-18.

Wu, Q., Zhang, X., Sun, J., Ma, Z., Zhou, C., 2016. Locked post-fossil consumption of urban decentralized solar photovoltaic energy: A case study of an on-grid photovoltaic power supply community in Nanjing, China. Appl. Energy 172, 1-11. doi:10.1016/j.apenergy.2016.03.013

Yang, C.-H., Lin, C.-H.A., 2008. DEVELOPING EMPLOYMENT EFFECTS OF INNOVATIONS: MICROECONOMETRIC EVIDENCE FROM TAIWAN. Dev. Econ. 46, 109-134. doi:10.1111/j.1746-1049.2008.00059.x

Yarden, Y., Caldes, C., 2013. Basic cancer research is essential for the success of personalised medicine. Eur. J. Cancer 49, 2619-2620. doi:10.1016/j.ejca.2013.04.020

Yin Y L, Lin G L. Notice of RetractionStudy on the government subsidy mechanism of city integrated transportation Hub based on externality theory[C]. IEEE International Conference on Advanced Management Science. IEEE, 2010:497-499.

Yu, F., Guo, Y., Le-Nguyen, K., Barnes, S.J., Zhang, W., 2016. The impact of government subsidies and enterprises' R\&D investment: A panel data study from renewable energy in China. Energy Policy 89, 106-113. doi:10.1016/j.enpol.2015.11.009

Yun, K., Tung-Yu, T., Yang-Kuang, O., 2008. Study of the time lag effect of patent impact on profitability of U.S. Pharmaceutical Industry from innovation to profit, in: PICMET '08 2008 Portland International Conference on Management of Engineering \& Technology. pp. 2588-2596. doi:10.1109/PICMET.2008.4599887

Zhang $H$, Li L, Zhou D, et al. Political connections, government subsidies and firm financial performance: Evidence from renewable energy manufacturing in China[J]. Renewable Energy, 2014, 63(1):330-336.

Zhang X, Zhang C. Optimal New Energy Vehicle Production Strategy Considering Subsidy and Shortage Cost $\mathcal{\imath}[\mathrm{J}]$. Energy Procedia, 2015, 75:2981-2986.

Zehir, C., Can, E., Karaboga, T., 2015. Linking Entrepreneurial Orientation to Firm Performance: The Role of Differentiation Strategy and Innovation Performance. Procedia - Soc. Behav. Sci. 210, 358-367. doi:10.1016/j.sbspro.2015.11.381

Zeng, M., Li, C., Zhou, L., 2013. Progress and prospective on the police system of renewable energy in China. Renew. Sustain. Energy Rev. doi:10.1016/j.rser.2012.11.048

Zhang, A., Zhang, Y., Zhao, R., 2003. A study of the R\&D efficiency and productivity of Chinese firms. J. Comp. Econ. 31, 444-464. doi:10.1016/S0147-5967(03)00055-6

Zhang, H., Li, L., Zhou, D., Zhou, P., 2014. Political connections, government subsidies and firm financial performance: Evidence from renewable energy manufacturing in China. Renew. Energy 63, 330-336. doi:10.1016/j.renene.2013.09.029

Zhang, H., Zheng, Y., Ozturk, U.A., Li, S., 2016. The impact of subsidies on overcapacity: A comparison of wind and solar energy companies in China. Energy 94, 821-827. doi:10.1016/j.energy.2015.11.054

Zhang, W., White, S., 2016. Overcoming the liability of newness: Entrepreneurial action and the emergence of China's private solar photovoltaic firms. Res. Policy 45, 604-617. doi:10.1016/j.respol.2015.11.005 
1074 Zhang, X., Wang, Y., 2017. How to reduce household carbon emissions: A review of experience and policy design considerations. Energy Policy 102, 116-124. doi:10.1016/j.enpol.2016.12.010

1077 
Table 3 Descriptive statistics and correlations ( $N=59)$

\begin{tabular}{|c|c|c|c|c|c|c|c|c|c|c|c|c|c|c|c|}
\hline Variables & Min & Max & Mean & Std. & Z & $P$ & ECG & IC & AGE & SIZE & R\&D2012 & $R \& D 2013$ & $\mathrm{R} \& \mathrm{D} 2014$ & GSB2014 & GSA2014 \\
\hline ECG & 19.23 & 25.3 & 21.62 & 1.16 & 0.8 & 0.544 & 1 & $\begin{array}{l}-.144 \\
(.280)\end{array}$ & $\begin{array}{l}.103 \\
(.440)\end{array}$ & $\begin{array}{l}.828^{\star * \star} \\
(.000)\end{array}$ & $\begin{array}{l}.703^{* \star *} \\
(.000)\end{array}$ & $\begin{array}{l}.693^{* * *} \\
(.000)\end{array}$ & $\begin{array}{l}.745^{* * *} \\
(.000)\end{array}$ & $\begin{array}{l}.621^{* * *} \\
(.000)\end{array}$ & $\begin{array}{l}.684^{* \star *} \\
(.000)\end{array}$ \\
\hline IC & 1 & 10 & 5.4 & 3.03 & 10.316 & 0.063 & & 1 & $\begin{array}{l}.158 \\
(.236)\end{array}$ & $\begin{array}{l}-.053 \\
(.694)\end{array}$ & $\begin{array}{l}-.133 \\
(.319)\end{array}$ & $\begin{array}{l}-.085 \\
(.524)\end{array}$ & $\begin{array}{l}-.046 \\
(.731)\end{array}$ & $\begin{array}{l}-.247 \\
(.062)\end{array}$ & $\begin{array}{l}-.244 \\
(.065)\end{array}$ \\
\hline AGE & 2.08 & 3.5 & 2.86 & 0.33 & 0.972 & 0.301 & & & 1 & $\begin{array}{l}.155 \\
(.244)\end{array}$ & $\begin{array}{l}.003 \\
(.981)\end{array}$ & $\begin{array}{l}.038 \\
(.778)\end{array}$ & $\begin{array}{l}.010 \\
(.940)\end{array}$ & $\begin{array}{l}.124 \\
(.353)\end{array}$ & $\begin{array}{l}.276^{*} \\
(.036)\end{array}$ \\
\hline SIZE & 5.87 & 11.2 & 7.99 & 1.11 & 0.472 & 0.979 & & & & 1 & $\begin{array}{l}.632^{\star \star *} \\
(.000)\end{array}$ & $\begin{array}{l}.641^{* \star \star} \\
(.000)\end{array}$ & $\begin{array}{l}.684^{\star * \star} \\
(.000)\end{array}$ & $\begin{array}{l}.638^{* \star \star} \\
(.000)\end{array}$ & $\begin{array}{l}.684^{* * *} \\
(.000)\end{array}$ \\
\hline R\&D2012 & 14.7 & 21.48 & 17.81 & 1.43 & 0.486 & 0.972 & & & & & 1 & $\begin{array}{l}.943^{* \star \star} \\
(.000)\end{array}$ & $\begin{array}{l}.738^{\star * *} \\
(.000)\end{array}$ & $\begin{array}{l}.391^{\star \star \star} \\
(.002)\end{array}$ & $\begin{array}{l}.583^{* * *} \\
(.000)\end{array}$ \\
\hline R\&D2013 & 14.81 & 21.4 & 17.92 & 1.44 & 0.729 & 0.663 & & & & & & 1 & $\begin{array}{l}.785^{\star \star} \\
(.000)\end{array}$ & $\begin{array}{l}.371^{\star *} \\
(.004)\end{array}$ & $\begin{array}{l}.549^{* \star \star} \\
(.000)\end{array}$ \\
\hline R\&D2014 & 13.32 & 21.84 & 17.91 & 1.61 & 0.65 & 0.792 & & & & & & & 1 & $\begin{array}{l}.458^{* * *} \\
(.000)\end{array}$ & $\begin{array}{l}.561^{\star \star \star} \\
(.000)\end{array}$ \\
\hline
\end{tabular}




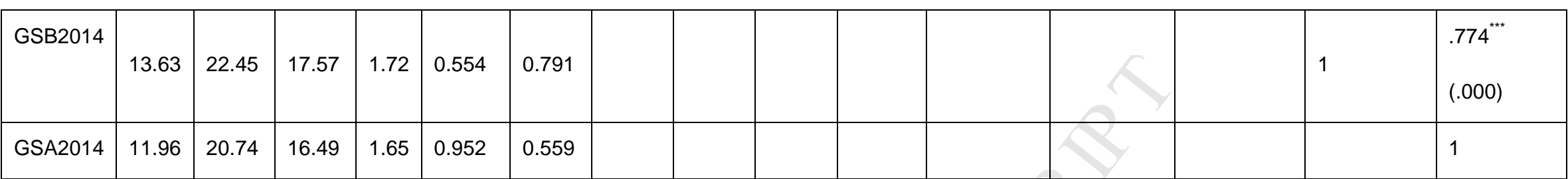

***. Correlation is significant at the 0.001 level (2-tailed)

**. Correlation is significant at the 0.01 level (2-tailed) 
Table 4. Results of hierarchical moderated regression analysis ( $N=58)$

\begin{tabular}{|c|c|c|c|c|}
\hline & Model 1 & Model 2 & Model 3 & Model 4 \\
\hline \multicolumn{5}{|c|}{ Control variables } \\
\hline IC & $\begin{array}{l}-0.099 \\
(-1.302)\end{array}$ & $\begin{array}{l}-0.083 \\
(-1.195)\end{array}$ & $\begin{array}{l}-0.051 \\
(-.690)\end{array}$ & $\begin{array}{l}-0.053 \\
(-0.814)\end{array}$ \\
\hline Age & $\begin{array}{r}-0.009 \\
(-.118)\end{array}$ & $\begin{array}{l}0.033 \\
(0.476)\end{array}$ & $\begin{array}{l}0.017 \\
(0.222)\end{array}$ & $\begin{array}{l}0.051 \\
(0.766)\end{array}$ \\
\hline Size & $\begin{array}{l}0.824^{* * *} \\
(10.811)\end{array}$ & $\begin{array}{l}0.547^{+* *} \\
(5.592)\end{array}$ & $\begin{array}{l}0.466 \\
(4.089)\end{array}$ & $\begin{array}{l}0.512^{+* *} \\
(5.538)\end{array}$ \\
\hline \multicolumn{5}{|c|}{ Independent Variables } \\
\hline R\&D2012 & & $\begin{array}{l}0.285 \\
(1.376)\end{array}$ & $\begin{array}{l}0.256 \\
(1.196)\end{array}$ & $\begin{array}{l}0.370 \\
(1.879)\end{array}$ \\
\hline R\&D2013 & & $\begin{array}{l}-0.149 \\
(-0.669)\end{array}$ & $\begin{array}{l}-0.107 \\
(-0.474)\end{array}$ & $\begin{array}{l}-0.157 \\
(-0.742)\end{array}$ \\
\hline R\&D2014 & & $\begin{array}{l}0.273^{*} \\
(2.305)\end{array}$ & $\begin{array}{l}0.250^{*} \\
(2.084)\end{array}$ & $\begin{array}{l}0.148 \\
(1.212)\end{array}$ \\
\hline
\end{tabular}




\begin{tabular}{|c|c|c|c|c|}
\hline GSB2014 & & & $\begin{array}{l}0.109 \\
(0.937)\end{array}$ & $\begin{array}{l}-0.356^{*} \\
(-2.270)\end{array}$ \\
\hline GSA2014 & & & $\begin{array}{l}0.033 \\
(0.249)\end{array}$ & $\begin{array}{l}0.455^{* *} \\
(2.907)\end{array}$ \\
\hline \multicolumn{5}{|l|}{ Interaction effects } \\
\hline R\&D2014 GSB2014 & & & & $\begin{array}{l}-0.360^{*} \\
(-2.282)\end{array}$ \\
\hline R\&D2014 GSA2014 & & & & $\begin{array}{l}0.444^{* *} \\
(2.812)\end{array}$ \\
\hline $\mathrm{R}^{2}$ & 0.696 & 0.769 & 0.778 & 0.805 \\
\hline Adj. $R^{2}$ & 0.679 & 0.742 & 0.741 & 0.773 \\
\hline$\triangle R^{2}$ & & $0.046^{* * *}$ & $0.009^{* * *}$ & 0.027 \\
\hline $\mathrm{F}$ & $41.158^{* * *}$ & $28.292^{* * *}$ & $21.423^{* * *}$ & $25.224^{* * *}$ \\
\hline
\end{tabular}

Note:

$1 . N=59$.

2.+ $p<0.1,{ }^{*} p<0.05,{ }^{* *} p<0.01,{ }^{* * *} p<0.001$. All reported significance levels are two-tailed.

3. Standardized coefficients are reported; the numbers in parenthesis are the $t$ values 


\section{Appendix: Basic Information of Samples}

\begin{tabular}{|c|c|c|c|}
\hline Samples & $\begin{array}{l}\text { Number of Employees } \\
\text { (2014) }\end{array}$ & Established Year & Sub-classification of Clean Energy \\
\hline Xinjiang Goldwind Science \& Technology Co., Ltd. & 5002 & 1998 & Wind power \\
\hline Titan Wind Energy (Suzhou) Co., Ltd. & 491 & 2005 & Wind power \\
\hline Shanghai Taisheng Wind Power Equipment Co., Ltd. & 868 & 2001 & Wind power \\
\hline Huayi Electric Co., Ltd. & 1803 & 1986 & Wind power \\
\hline Ning Xia Yin Xing Energy Co., Ltd. & 749 & 1998 & Wind power \\
\hline Xiangtan Electric Manufacturing Co., Ltd. & 7499 & 1999 & Wind power \\
\hline Shanghai Hi-Tech Control System Co., Ltd. & 1170 & 2000 & Wind power \\
\hline Sufa Technology Industry Co., Ltd., CNNC & 1221 & 1997 & Nuclear power \\
\hline Shenzhen Woer Heat-shrinkable Material Co., Ltd. & 4088 & 1998 & Nuclear power \\
\hline Jiangsu Shentong Valve Co., Ltd. & 750 & 2007 & Nuclear power \\
\hline Zhejiang Jiuli Hi-tech Metals Co., Ltd. & 2587 & 1987 & Nuclear power \\
\hline Dongfang Electric Co., Ltd. & 21379 & 1993 & Nuclear power \\
\hline Shanghai Electric Group Co., Ltd. & 29261 & 2014 & Nuclear power \\
\hline SDIC Power Holdings Co., Ltd. & 7415 & 2014 & Hydropower \\
\hline Sichuan Chuangtou Energy Co., Ltd. & 910 & 1988 & Hydropower \\
\hline
\end{tabular}




\begin{tabular}{|c|c|c|c|}
\hline Hubei Energy Group Co., Ltd. & 3646 & 1993 & Hydropower \\
\hline GD Power Development Co., Ltd. & 28335 & 1992 & Hydropower \\
\hline Guangxi Guiguan Electric Power Co., Ltd. & 2853 & 1992 & Hydropower \\
\hline TBEA Co., Ltd. & 15488 & 1993 & Photovoltaic power \\
\hline Hareon Solar Technology Co., Ltd. & 4257 & 2004 & Photovoltaic power \\
\hline Jiangsu Akcome Science \& Technology Co., Ltd. & 2251 & 2006 & Photovoltaic power \\
\hline Xi'an Longi Silicon Materials Corp. & 5451 & 2000 & Photovoltaic power \\
\hline SUNGROW & 1164 & 1997 & Photovoltaic power \\
\hline Huabei Expressway Co., Ltd. & 1003 & 1999 & Photovoltaic power \\
\hline Zhongli Sci-Tech Group Co., Ltd. & 5427 & 1996 & Photovoltaic power \\
\hline Wuxi Little Swan Co., Ltd. & 8497 & 1993 & Solar energy \\
\hline Sichuan Minjiang Hydropower Co., Ltd. & 809 & 1993 & Solar energy \\
\hline Shengyi Technology Co., Ltd. & 9018 & 1985 & Solar energy \\
\hline Ningbo Weken Co., Ltd. & 6047 & 1998 & Solar energy \\
\hline Advanced Technology \& Materials Co., Ltd. & 6414 & 1998 & Solar energy \\
\hline Lanzhou Great Wall Electric Co., Ltd. & 4082 & 1998 & Solar energy \\
\hline Leshan Electric Power Co., Ltd. & 4469 & 1988 & Solar energy \\
\hline Nanjing Huadong Electronics Information \& Technology & 3378 & 1993 & Solar energy \\
\hline
\end{tabular}




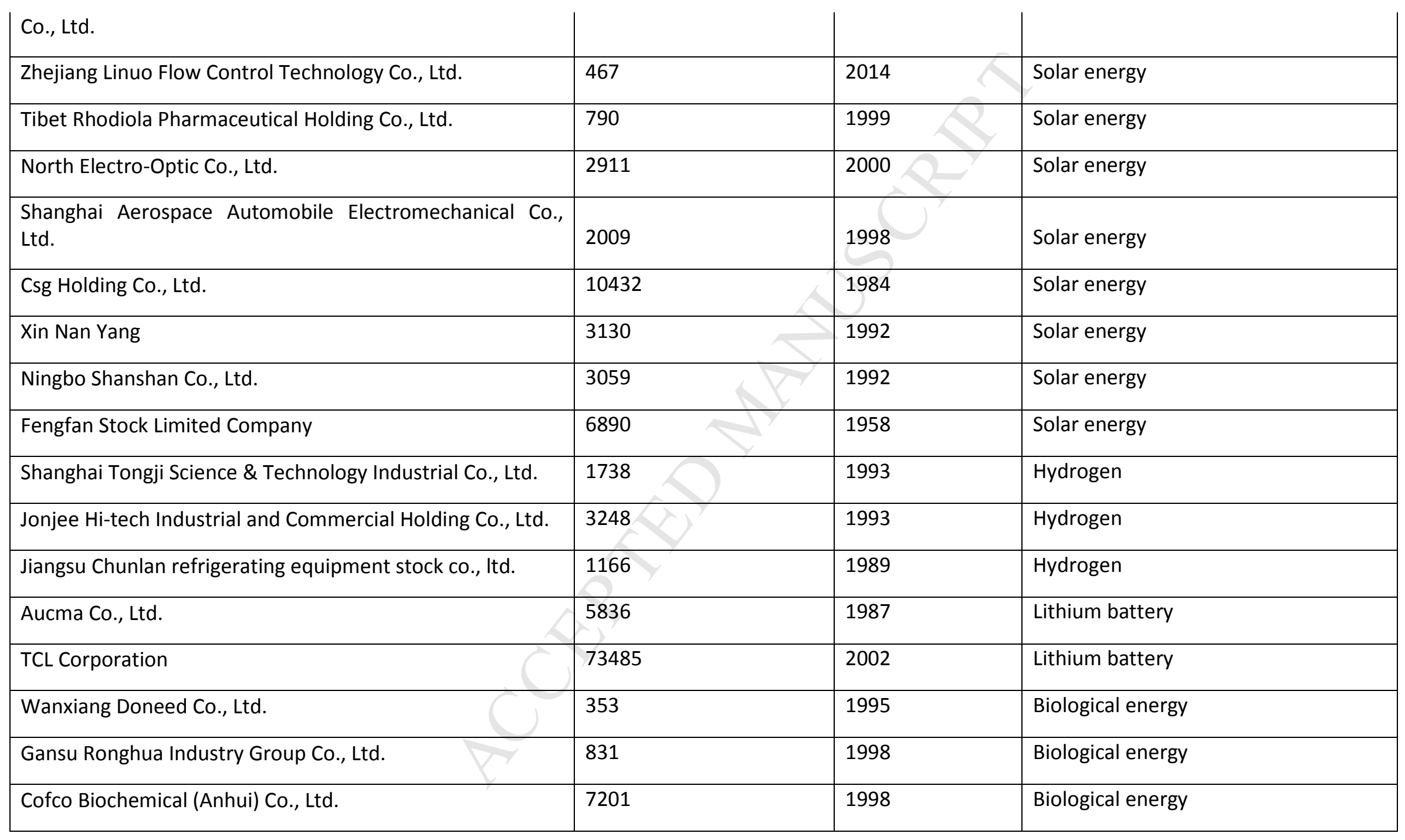




\begin{tabular}{|c|c|c|c|}
\hline Jiangmen Sugarcane Chemical Factory (Group) Co., Ltd. & 626 & 1993 & Biological energy \\
\hline Baotou Huazi Industry Co., Ltd.. & 541 & 1998 & Biological energy \\
\hline Hainan Yedao Group Co., Ltd. & 963 & 1993 & Biological energy \\
\hline Wuxi Huaguang Boiler Co., Ltd. & 2410 & 2006 & Biological energy \\
\hline Huadian Power International Corporation Limited & 24399 & 1994 & Biological energy \\
\hline ZZEFU Co., Ltd. & 1674 & 2008 & Tidal energy \\
\hline Zhejiang Dunan Artificial Environment Co., Ltd. & 9374 & 2001 & Geothermal energy \\
\hline Yantai Moon Co., Ltd. & 1776 & 1989 & Geothermal energy \\
\hline Dalian Refrigeration Co., Ltd. & 2030 & 1993 & Geothermal energy \\
\hline Shanghai Highly (GROUP) Co., Ltd. & 4730 & 1992 & Geothermal energy \\
\hline Shanghai Hanbell Precise Machinery Co., Ltd. & 663 & 1998 & Geothermal energy \\
\hline Zhejiang Weixing New Building Materials Co., Ltd. & 2911 & 2007 & Geothermal energy \\
\hline Guangzhou Seagull Kitchen and Bath Products Co., Ltd. & 4101 & 2003 & Geothermal energy \\
\hline Haerbin Air Conditioning Co., Ltd. & 862 & 1952 & Geothermal energy \\
\hline Zhejiang IDC Fluid Control Co., Ltd. & 2616 & 2001 & Geothermal energy \\
\hline Jiangsu Changfa Refrigeration CO., LTD. & 3338 & 2002 & Geothermal energy \\
\hline Shuangliang Eco-energy Systems CO., LTD. & 3087 & 1982 & Geothermal energy \\
\hline
\end{tabular}

